\title{
Arsenic compounds activate the MAPK and caspase pathways to induce apoptosis in OEC-M1 gingival epidermal carcinoma
}

\author{
NING-PING FOO ${ }^{1,2^{*}}$, CHI-LIN KO ${ }^{1 *}$, CHIAO-YUN CHU ${ }^{3 *}$, \\ CHIA-YIH WANG ${ }^{3 *}$, EDMUND CHEUNG SO ${ }^{2,4}$ and BU-MIIN HUANG ${ }^{3,5}$ \\ ${ }^{1}$ Department of Emergency Medicine, An Nan Hospital, China Medical University, Tainan 70965; \\ ${ }^{2}$ Graduate Institute of Medical Sciences, Chang Jung Christian University, Tainan 71101; \\ ${ }^{3}$ Department of Cell Biology and Anatomy, College of Medicine, National Cheng Kung University, Tainan 70101; \\ ${ }^{4}$ Department of Anesthesia, An Nan Hospital, China Medical University, Tainan 70965; \\ ${ }^{5}$ Department of Medical Research, China Medical University Hospital, Taichung 40406, Taiwan, R.O.C.
}

Received April 14, 2020; Accepted August 31, 2020

DOI: 10.3892/or.2020.7793

\begin{abstract}
Arsenic is a well-documented environmental toxicant that can induce neurotoxicity and peripheral vascular diseases. In fact, arsenic trioxide has been used to treat various cancer types. Oral cancer has been in the top ten common cancers for decades in Taiwan, and the incidence rate is continuously increasing. The majority of oral cancers are associated with excessive tobacco, alcohol consumption and betel chewing. To the best of our knowledge, no study has revealed the effect of arsenic compounds on oral cancers. Thus, the present study used OEC-M1 oral squamous carcinoma cells treated with sodium arsenite $\left(\mathrm{NaAsO}_{2}\right)$ and dimethylarsenic acid (DMA) to determine whether both arsenic compounds could exert anticancer effects on oral cancer. The results demonstrated that $\mathrm{NaAsO}_{2}$ and DMA induced rounding up and membrane blebbing in OEC-M1 cells, which are morphological characteristics of apoptosis. Annexin V/PI double staining analysis further confirmed that both arsenic compounds induced apoptosis of OEC-M1 cells. In addition, $\mathrm{NaAsO}_{2}$ and DMA significantly decreased the survival rate and increased the percentage of OEC-M1 cells in the subG1 and $\mathrm{G} 2 / \mathrm{M}$ phases $(\mathrm{P}<0.05)$. Furthermore, both arsenic compounds significantly activated the cleavage of
\end{abstract}

Correspondence to: Professor Bu-Miin Huang, Department of Cell Biology and Anatomy, College of Medicine, National Cheng Kung University, 1 University Road, Tainan 70101, Taiwan, R.O.C.

E-mail: bumiin@mail.ncku.edu.tw

Professor Edmund Cheung So, Graduate Institute of Medical Sciences, Chang Jung Christian University, 1 Changda Road, Gueiren, Tainan 71101, Taiwan, R.O.C.

E-mail: edmundsotw@gmail.com

${ }^{*}$ Contributed equally

Key words: sodium arsenite, dimethylarsenic acid, oral cancer, OEC-M1, apoptosis, caspase pathway, MAPK pathway caspase- $8,-9,-3$ and PARP, and the phosphorylation of JNK, ERK1/2 and p38 in OEC-M1 cells $(\mathrm{P}<0.05)$. Collectively, the findings of the present study indicated that $\mathrm{NaAsO}_{2}$ and DMA stimulate extrinsic and intrinsic apoptotic pathways through the activation of the MAPK pathways to induce apoptosis of OEC-M1 cells, suggesting that $\mathrm{NaAsO}_{2}$ and DMA may be used as novel anticancer drugs for oral cancers.

\section{Introduction}

The most frequent malignant tumor of the head and neck region is squamous cell carcinoma, which typically develops in males $(1,2)$. Squamous cell carcinoma is strongly associated with certain environmental and lifestyle risk factors, including tobacco smoking, alcohol consumption, UV light exposure and infection with high-risk types of human papillomavirus (3). In addition, betel chewing in Southeast Asia is known to be a strong risk factor for developing oral cavity cancers (4). Squamous cell carcinoma can be treated through surgery, radiation therapy and chemotherapy, as well as new investigative treatments, such as immunotherapy and gene therapy (5). Oral cancer has been in the top ten common cancers for decades in Taiwan, with a continuing annual increase in its incidence rate (6).

Arsenic is a naturally occurring element distributed throughout the earth's crust, which exhibits both metallic and non-metallic properties (7). In the environment, arsenic is combined with oxygen, chlorine and sulfur to form inorganic arsenic compounds; while in animals and plants it combines with carbon and hydrogen to form organic arsenic compounds. In general, inorganic arsenic is more toxic than organic arsenic (8). Arsenic has long been applied as a pesticide for agricultural use due to its poisonous effects. In addition, arsenic trioxide (ATO) has been discovered to exert antitumor effects in patients with acute promyelocytic leukemia (APL) for clinical trial (9). Several studies have reported that ATO induces apoptosis of malignant cells, including APL (10), multiple myeloma (11), lung cancer (12), liver cancer (13), cholangiocarcinoma (14), testicular cancer (15) and ovarian cancer (16) cells with in vitro and in vivo studies. Another inorganic arsenic 
compound, arsenic hexoxide, has also been reported to exert anticancer effects on MCF-7 human breast cancer cells (17) and colon cancer (18). Furthermore, an organic arsenic derivative (OAD), darinaparsin, is potentially safer and more effective for the treatment of hematological and solid tumors according to preclinical models (19). Dipropil-S-glycerol arsenic, a novel OAD, also exhibits antiproliferative activity by inducing apoptosis of human acute myeloid leukemia cell lines (20). Therefore, inorganic and organic arsenic compounds possess the ability to suppress tumor progression in vitro and in vivo. To the best of our knowledge, no study has yet determined whether arsenic compounds exert any effects on normal gingival fibroblasts or any anticancer effects on oral tumors.

The unifying characteristics of apoptosis are largely morphological, including cell shrinkage, blebbing of the plasma membrane, chromatin condensation and DNA fragmentation $(21,22)$. Apoptosis can be distinguished into the extrinsic and intrinsic pathways based on the initial stimuli and regulatory caspase (aspartate-specific cysteine protease) cascade. The extrinsic pathway, also termed the death receptor pathway, is activated by death receptors when bound by the appropriate ligand. Upon binding, a trimerized receptor recruits the signal transducing molecules through interaction with death domains, which leads to the cleavage of pro-caspase- 8 . Activated caspase- 8 initiates a protease cascade that cleaves targets within a cell and results in apoptotic cell death (23). Conversely, the intrinsic pathway is dependent on the decrease of mitochondrial membrane potential. When cellular stress occurs, cytochrome $c$ is released from the mitochondrial intermembrane space into the cytosol. Subsequently, it binds to an adapter protein, apoptotic protease activating factor 1 , which acts to recruit pro-caspase- 9 . Active caspase- 9 subsequently cleaves pro-caspase-3, which is then released into the cytosol to affect the proteolytic degradation of its target substrates (23). Both apoptotic pathways can activate downstream effector caspases and lead to poly(ADP-ribose) polymerase (PARP) cleavage, which inhibits the cellular function of DNA repair $(24,25)$. In fact, previous studies have demonstrated that ATO can induce apoptosis with downregulation of Bcl-2 expression and activation of a caspase cascade $(24,25)$.

Mitogen-activated protein kinases (MAPKs), which are crucial for the maintenance of cell proliferation, differentiation, mitosis, cell survival, gene expression and apoptosis, consist of three family members: c-Jun NH2-terminal kinase [(JNK)1, 2 and 3]; extracellular signal-regulated kinase (ERK1 and 2); and p38 MAPKs (p38-MAPK $\alpha, \beta, \gamma$ and $\delta$ ) $(26,27)$. MAPKs are serine/threonine/tyrosine-specific protein kinases involved in directing cellular responses to diverse stimuli $(26,27)$. Depending on the cell type and stimulus, MAPKs promote cell survival or trigger cell death. JNK and ERK activities have been reported to sensitize ovarian carcinoma cells to cisplatin-induced apoptosis (28). In addition, phosphorylation of JNK and p38 is increased in response to ATO treatment, resulting in mitochondrial apoptotic cell death in human cervical cancer cells (29).

On account of the anticancer ability of arsenic compounds and emerging demands for more effective therapeutic remedies to treat oral cavity cancer, OEC-M1 cells, derived from a surgical specimen of buccal mucosa squamous carcinoma from a Taiwanese as a unique indigenous oral cancer cell line $(30,31)$, were used in the present study. Cells treated with sodium arsenite $\left(\mathrm{NaAsO}_{2}\right)$ and dimethylarsenic acid $\left[\left(\mathrm{CH}_{3}\right)_{2} \mathrm{AsO}_{2} \mathrm{H}\right.$; DMA] were investigated to determine whether the arsenic compounds could affect cell viability, regulate cell cycle progression, modulate signaling pathways, and then induce apoptosis with anticancer capabilities.

\section{Materials and methods}

Chemicals. $\mathrm{NaAsO}_{2}$ was purchased from Fluka; Sigma-Aldrich. DMA, high glucose Dulbecco's modified Eagle's medium, penicillin-streptomycin, staurosporine, RNase A, propidium iodide, $30 \%$ acrylamide/Bis-acrylmide solution, methylthiazole tetrazolium (MTT) and monoclonal antibody against $\beta$-actin were purchased from Sigma-Aldrich; Merck KGaA. Fetal bovine serum and trypsin-EDTA were purchased from AG Scientific, Inc. RPMI-1640 medium, Dulbecco's modified Eagle's medium/F12 and Keratinocyte-SFM medium were purchased from Gibco; Thermo Fisher Scientific, Inc. Sodium chloride, potassium chloride, 4-(2-hydroxyethyl)-1-piperazineethanesulfonic acid (HEPES) and Tris base were purchased from JT Baker. Disodium hydrogen phosphate $\left(\mathrm{Na}_{2} \mathrm{HPO}_{4}\right)$, potassium dihydrogen phosphate $\left(\mathrm{KH}_{2} \mathrm{PO}_{4}\right)$ and sodium bicarbonate $\left(\mathrm{NaHCO}_{3}\right)$ were purchased from Riedel-de Haen. Hydrochloric acid, sodium hydroxide, sodium dodecyl sulfate (SDS), Tween-20 and dimethyl sulfoxide (DMSO) were purchased from Merck KGaA. Donkey anti-rabbit IgG conjugated to horseradish peroxidase and donkey anti-mouse IgG conjugated to horseradish peroxidase were purchased from PerkinElmer, Inc. Annexin V-FITC apoptosis detection kit was purchased from Strong Biotech. Micro BCA protein assay kit was purchased from Thermo Fisher Scientific, Inc. Antibodies against PARP, cleaved caspase-8, cleaved caspase-9, cleaved caspase-3, phosphorylated (p)-JNK, JNK, p-ERK1/2, ERK1/2,p-p38 and p38 were purchased from Cell Signaling Technology, Inc. Enhanced chemiluminescence (ECL) detection kit was purchased from EMD Millipore.

Cell culture. OEC-M1 is a cell line derived from a surgical specimen of buccal mucosa squamous carcinoma from a Taiwanese, a unique oral cancer indigenous in Taiwan, and was a generous gift from Professor Kuo-Wei Chang (National Yang-Ming University, Taipei, Taiwan) (30,31). OEC-M1 cells were maintained in RPMI-1640 medium supplemented with $24 \mathrm{mM} \mathrm{NaHCO}$, $25 \mathrm{mM}$ HEPES, 10,000 U penicillin and 10,000 $\mu \mathrm{g}$ streptomycin (both from Sigma-Aldrich; Merck $\mathrm{KGaA}$ ) and $10 \%$ heat-inactivated fetal bovine serum, $\mathrm{pH} 7.4$, incubated in a humidified atmosphere containing $95 \%$ air and $5 \% \mathrm{CO}_{2}$ at $37^{\circ} \mathrm{C} \mathrm{(32).}$

Morphological observation. OEC-M1 cells were seeded at a concentration of $6 \times 10^{5}$ cells in a $6-\mathrm{cm}$ Petri dish with $2 \mathrm{ml}$ culture medium. After reaching 70-80\% confluence, cells were treated without or with various concentrations of $\mathrm{NaAsO}_{2}(0.1,1,10,25,50$ and $100 \mu \mathrm{M})$, or various concentrations of DMA $(0.1,1,2,5,10,25,50$ and $100 \mathrm{mM})$ for $24 \mathrm{~h}$. Cell morphology was then observed under an Olympus CK40 light microscope and recorded by an Olympus DP20 digital camera (Olympus Corporation). 
MTT viability test. OEC-M1 cells were seeded at a concentration of $1 \times 10^{4}$ cells/well with $100 \mu \mathrm{l}$ culture medium. After reaching $70-80 \%$ confluence, cells were treated without or with various concentrations of $\mathrm{NaAsO}_{2}(0.1,1,10,25,50$ and $100 \mu \mathrm{M})$ or various concentrations of DMA $(0.1,1,10,25,50$ and $100 \mathrm{mM}$ ) for $24 \mathrm{~h}$. MTT was added to a final concentration of $0.5 \mathrm{mg} / \mathrm{ml}$ and incubated at $37^{\circ} \mathrm{C}$ for $4 \mathrm{~h}$. The medium was discarded and $50 \mu \mathrm{l}$ DMSO was added to each well to dissolve the crystals by shaking the plate for $20 \mathrm{~min}$ in the dark $(33,34)$. The absorbance values in each treatment group were determined at a wavelength of $570 \mathrm{~nm}$ by VersaMax ELISA reader (Molecular Devices, LLC).

Cell cycle analysis. To further confirm whether $\mathrm{NaAsO}_{2}$ and DMA could induce apoptosis among these oral cancer cell lines, the redistribution of the cell cycle was examined by flow cytometric analysis through propidium iodide (PI) staining. OEC-M1 cells were seeded at a concentration of $6 \times 10^{5}$ cells. After reaching 70-80\% confluence, cells were treated without or with various concentrations of $\mathrm{NaAsO}_{2}(0.1,1,10,25,50$ and $100 \mu \mathrm{M})$, or various concentrations of DMA $(0.1,1,10,25,50$ and $100 \mathrm{mM}$ ) for $24 \mathrm{~h}$. Treated cells were harvested by trypsin and centrifuged $\left(400 \mathrm{x} \mathrm{g}\right.$ for $12 \mathrm{~min}$ at $4^{\circ} \mathrm{C}$ ), and then washed by isoton II and fixed in $70 \%$ ethanol at $-20^{\circ} \mathrm{C}$ for $\geq 2 \mathrm{~h}$. After fixation, cells were washed with isoton II again and collected by centrifugation $\left(400 \mathrm{x} \mathrm{g}\right.$ for $12 \mathrm{~min}$ at $\left.4^{\circ} \mathrm{C}\right)$. Cell pellets were resuspended with isoton II and mixed with $100 \mu \mathrm{g} / \mathrm{ml}$ RNase and $40 \mu \mathrm{g} / \mathrm{ml}$ PI for $30 \mathrm{~min}$ (15). The stained cells were analyzed using a flow cytometer (FACScan; BD Biosciences) with excitation set at a wavelength of $488 \mathrm{~nm}$. The DNA contents of normal cells in the G1 phase are diploid, while that in the $\mathrm{G} 2 / \mathrm{M}$ phase increases after DNA synthesis progression. Cells in the subG1 phase have less DNA contents in cell cycle distribution, which is called hypodiploid and considered as an outcome of cell apoptosis $(34,35)$. The percentages of sub-G1, $\mathrm{S}$ and $\mathrm{G} 2 / \mathrm{M}$ phase cells were analyzed using FACStation v6.1x and Modfit LT v3.3 software (BD Biosciences).

Annexin V/PI double staining assay. Treated cells were harvested by trypsin and washed with $2 \mathrm{ml}$ culture medium. Following centrifugation at $160 \mathrm{xg}$ for $10 \mathrm{~min}$ at $4^{\circ} \mathrm{C}$, the pellets were resuspended with cold isoton II and centrifuged ( $400 \mathrm{x} \mathrm{g}$ for $12 \mathrm{~min}$ at $4^{\circ} \mathrm{C}$ ) again. The pellets were subsequently mixed with $100 \mu \mathrm{l}$ staining solution for $15 \mathrm{~min}$ according to the user's manual of the Annexin V-FITC apoptosis detection kit (Strong Biotech). The stained cells were analyzed at a wavelength of $488 \mathrm{~nm}$ excitation using a 515-nm band pass filter for FITC detection and $>600-\mathrm{nm}$ band pass filter for PI detection by a FACScan flow cytometer (BD Biosciences). The plots were divided into four quadrants, which represent negative staining (viable) cells, Annexin V-positive (early apoptosis) cells, PI-positive (necrosis) cells, and Annexin V/PI double-positive (late apoptosis) cells. In addition, cells were also treated with staurosporine which was considered as a positive control. The percentage of cells in the 4 quadrants was analyzed using FACStation v6.1x software.

Protein extraction and immunoblotting analysis. Cells $\left(6 \times 10^{5}\right)$ were seeded in a 60-mm dish. After reaching 70-80\% confluence, cells were treated without or with various concentrations of $\mathrm{NaAsO}_{2}(10$ and $25 \mu \mathrm{M})$, or various concentrations of DMA (10 and $25 \mathrm{mM}$ ) for 3, 6, 12 and $24 \mathrm{~h}$. Medium was then transferred to a $15-\mathrm{ml}$ tube, and centrifuged at $1,500 \mathrm{x} \mathrm{g}$ for $10 \mathrm{~min}$ at $4^{\circ} \mathrm{C}$. Attached cells were lysed using $100 \mu \mathrm{l}$ lysis buffer with proteinase inhibitor (cat. no. P8340; Sigma-Aldrich; Merck KGaA). The pellets were resuspended with $10 \mu 1$ lysis buffer, blended into cell lysates, and centrifuged at $12,000 \mathrm{x} \mathrm{g}$ for $12 \mathrm{~min}$ at $4^{\circ} \mathrm{C}$. The supernatants were collected and stored at $-80^{\circ} \mathrm{C}$. The protein concentrations of cell lysates were determined by the Lowry assay $(35,36)$.

For immunoblotting analysis, cell lysates $(30 \mu \mathrm{g})$ were resolved on $12 \%$ SDS-PAGE gel with standard running buffer at room temperature, and electrophoretically transferred to polyvinyldifluoride membranes at $4^{\circ} \mathrm{C}$. The membranes were blocked in $4 \%$ milk for $1 \mathrm{~h}$ at room temperature and incubated with primary antibodies [cleaved caspase-8 (product no. 9429; 1:1,000), cleaved caspase-9 (product no. 9509; 1:1,000), cleaved caspase-3 (product no. 9661; 1:1,000), cleaved PARP (product no. 9542; 1:1,000), phospho-JNK (product no. 9251; 1/4,000), JNK (product no. 9252; 1:1,000), phospho-ERK1/2 (product no. 9101; 1:4,000), ERK1/2 (product no. 9102; 1:4,000), phospho-p38 (product no. 9215; 1:1,000), p38 (product no. 9212; 1:4,000)] overnight at $4^{\circ} \mathrm{C}$. Following washing with TBS Tween-20 and incubation with horseradish peroxidase-conjugated secondary antibodies for $1 \mathrm{~h}$ at room temperature [Donkey anti-rabbit IgG; cat. no. NEF81200-1EA; 1:2,000], the membranes were visualized using the ECL detection kit and UVP EC3 BioImaging Systems (UVP; Analytik Jena) (37). The quantification of each band was performed using the ImageJ version 1.50 software (National Institutes of Health).

Statistical analysis. The data are expressed as the mean \pm standard error of the mean (SEM) of at least three independent experiments. The statistical significance of differences between the control and treatment groups was determined by one-way ANOVA, followed by Tukey's post hoc test comparisons. Statistical analysis was performed with GraphPad Prism 6 software (GraphPad Software, Inc.). $\mathrm{P}<0.05$ was considered to indicate a statistically significant difference.

\section{Results}

Effects of arsenic compounds on morphological changes in OEC-M1 cells. OEC-M1 cells were treated with medium, $\mathrm{NaAsO}_{2}$ (trivalent arsenic) $(0.1,1,10,25,50$ and $100 \mu \mathrm{M})$ or DMA (penta-valent arsenic) $(0.1,1,10,25,50$ and $100 \mathrm{mM})$ for $24 \mathrm{~h}$, and the morphological changes were examined. In the experiment with $\mathrm{NaAsO}_{2}$, OEC-M1 cells exhibited a spindle-like shape in the control group (Fig. 1A), and became rounded up and suspended in the medium as the concentration increased, with the number of attached cells considerably decreasing in the $25-100 \mu \mathrm{M}$ treatment groups (Fig. 1E-G). In the DMA experiment, cells started to float in the groups of OEC-M1 cells treated with 0.1-1 mM DMA (Fig. 1H and I). As the concentration of DMA increased, cells shrank with membrane blebbing, indicating that they were undergoing apoptosis (Fig. 1H-M). Floating cells tended to aggregate in a high concentration of DMA treatment compared with $\mathrm{NaAsO}_{2}$ treatment. These results indicated that both $\mathrm{NaAsO}_{2}$ 

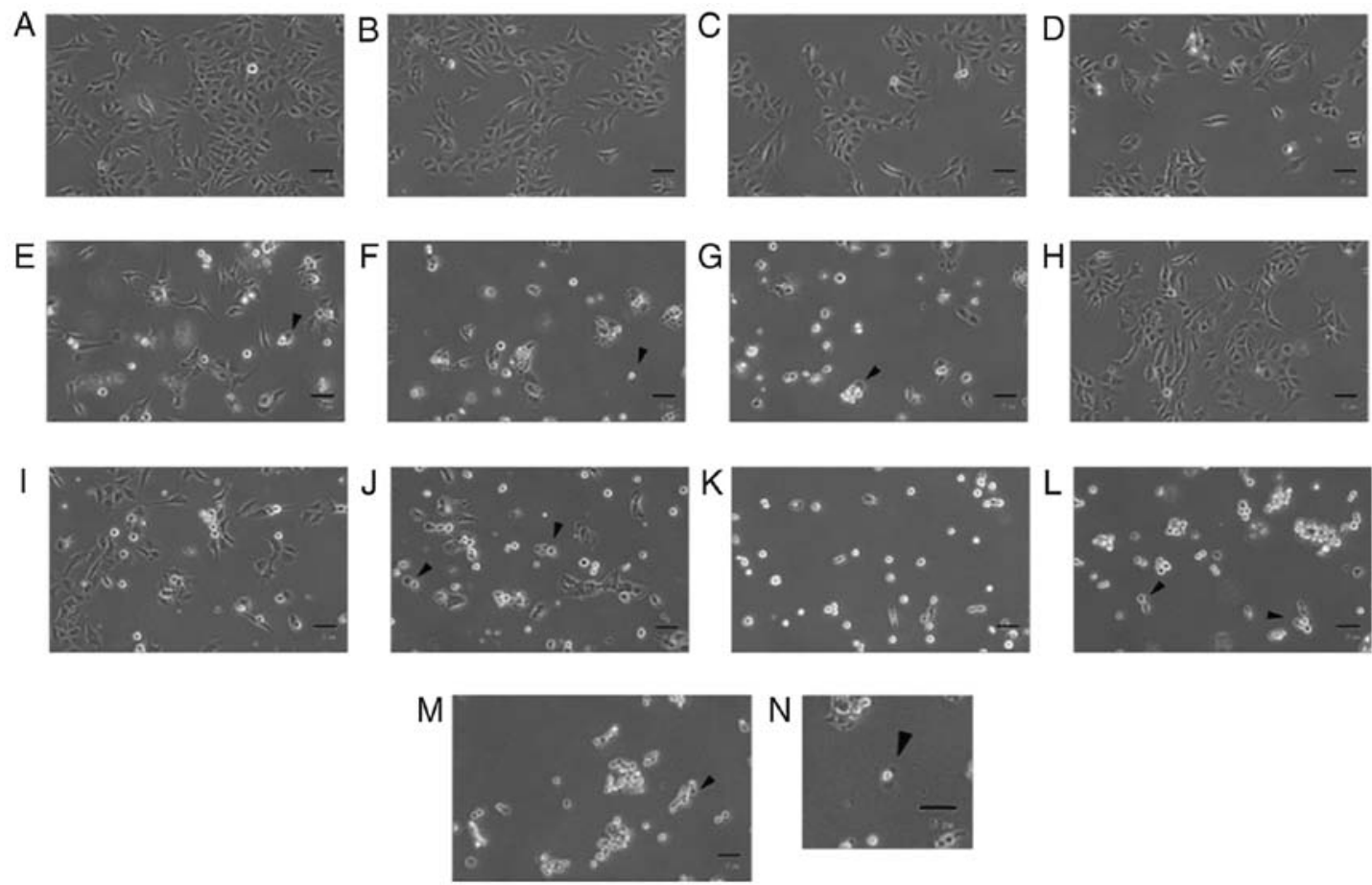

Figure 1. Effects of arsenic compounds on morphological changes in OEC-M1 cells. Cells were treated with (A) plain medium, (B-G) 0.1, 1, 10, 25, 50 and $100 \mu \mathrm{M}$ sodium arsenite, respectively, or (H-M) $0.1,1,10,25,50$ and $100 \mathrm{mM}$ dimethylarsenic acid in OEC-M1 cells for $24 \mathrm{~h}$, respectively. Morphological changes were observed under light microscopy (scale bar, $50 \mu \mathrm{m}$ ). Arrowheads indicate membrane-blebbing cells. (N) Apoptotic cell (scale bar, $10 \mu \mathrm{m}$ ). The arrowhead indicates an apoptotic cell with membrane blebbing). Experiments were performed three times with similar results.
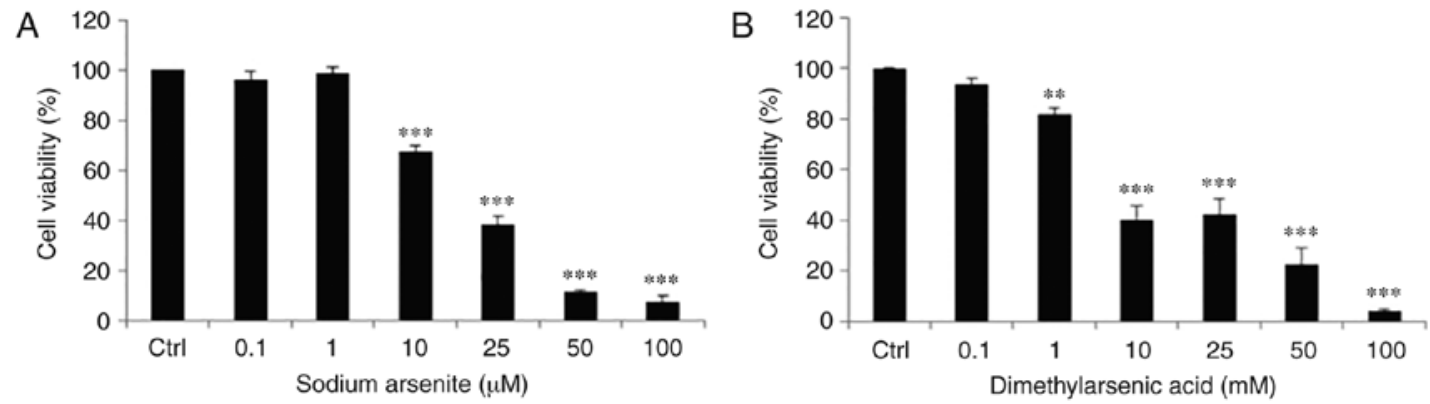

Figure 2. Effects of arsenic compounds on cell viability in OEC-M1 cells. Cells were treated with (A) $0,0.1,1,10,25,50$ and $100 \mu \mathrm{M} \mathrm{NaAsO}{ }_{2}$, or (B) 0 , $0.1,1,10,25,50$ and $100 \mathrm{mM}$ DMA for $24 \mathrm{~h}$. Cell viability was quantified by MTT assay. Results are expressed as percentages of cell growth relative to the control groups as $100 \%$. The data are expressed as mean \pm SEM of at least three separate experiments. ${ }^{* * *} \mathrm{P}<0.01$ and ${ }^{* * * *} \mathrm{P}<0.001$ represent statistical differences compared to the Ctrl. $\mathrm{NaAsO}_{2}$, sodium arsenite; DMA, dimethylarsenic acid; SEM, standard error of the mean; Ctrl, control.

and DMA could induce the morphological changes associated with apoptosis in OEC-M1 oral cancer cells.

Effects of arsenic compounds on the viability of OEC-MI cells. The survival rate of OEC-M1 cells treated with arsenic compounds was further examined by MTT cell viability assay. Cells were treated with medium, $\mathrm{NaAsO}_{2}(0.1,1,10,25,50$ and $100 \mu \mathrm{M})$ or DMA $(0.1,1,10,25,50$ and $100 \mathrm{mM})$ for $24 \mathrm{~h}$. The OEC-M1 cell survival rate was significantly decreased by $\mathrm{NaAsO}_{2}$ at doses of 10-100 $\mu \mathrm{M}$ (Fig. 2A) and by DMA from 1-100 mM (Fig. 2B) in dose-dependent manners $(\mathrm{P}<0.05)$. The concentration of DMA required to reduce cell viability to $50 \%$ in OEC-M1 cells was $\sim 1,000$-times higher compared with that of $\mathrm{NaAsO}_{2}$.

Effects of arsenic compounds on cell cycle distribution of OEC-M1 cells. To assess whether $\mathrm{NaAsO}_{2}$ and DMA could induce OEC-M1 oral cancer cell death via apoptosis, cells were treated with arsenic compounds and then evaluated for their DNA contents by PI staining via flow cytometric analysis. Thus, OEC-M1 cells were treated with medium, $\mathrm{NaAsO}_{2}$ $(0.1,1,10,25,50$ and $100 \mu \mathrm{M})$ or $\operatorname{DMA}(0.1,1,10,25,50$ and $100 \mathrm{mM}$ ) for $24 \mathrm{~h}$, and the changes in the number of cells in the subG1, G1 and G2/M phases related to cell cycle regulation were investigated.

$\mathrm{NaAsO}_{2}$ at 50 and $100 \mu \mathrm{M}$ significantly increased the number of cells in the subG1 phase in OEC-M1 cells (Fig. 3A and B) $(\mathrm{P}<0.05)$. In addition, the number of cells in the $\mathrm{G} 1$ phase was decreased by $25-100 \mu \mathrm{M} \mathrm{NaAsO} \mathrm{N}_{2}$ in OEC-M1 cells (Fig. 3A and $\mathrm{C})(\mathrm{P}<0.05)$. Furthermore, 25-100 $\mu \mathrm{M} \mathrm{NaAsO}$ significantly increased the number of OEC-M1 cells in the G2/M phase (Fig. 3A and D) $(\mathrm{P}<0.05)$. DMA at 1, 10, 50 and $100 \mathrm{mM}$ significantly increased 

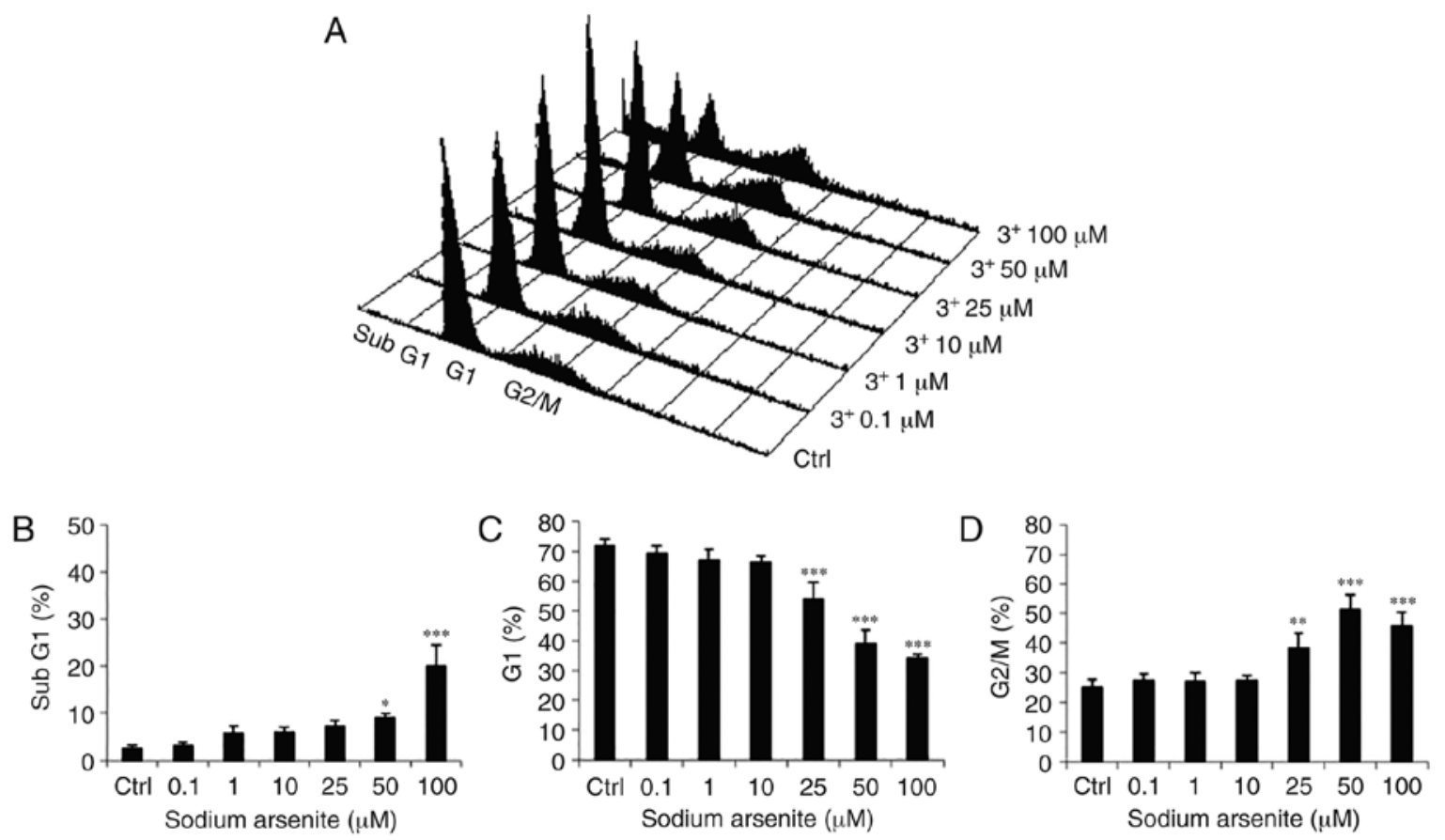

Figure 3. Effects of $\mathrm{NaAsO}_{2}$ on cell cycle redistribution in OEC-M1 cells. (A) Various concentrations of $\mathrm{NaAsO}_{2}(0,0.1,1,10,25,50$ and $100 \mu \mathrm{M})$ were used to treat OEC-M1 for $24 \mathrm{~h}$. Cells were fixed, stained with PI, and analyzed by flow cytometry. Cells in subG1 phase contain less DNA content than normal cells, indicating apoptosis. The percentage of (B) sub G1, (C) G1 and (D) G2/M phase cells are presented, respectively. The data are expressed as the mean \pm SEM of at least three separate experiments. ${ }^{*} \mathrm{P}<0.05,{ }^{* * *} \mathrm{P}<0.01$, and ${ }^{* * *} \mathrm{P}<0.001$ represent statistical differences compared to the $\mathrm{Ctrl}$ group. $\mathrm{NaAsO}_{2}$, sodium arsenite; PI, propidium iodide; SEM, standard error of the mean; Ctrl, control.
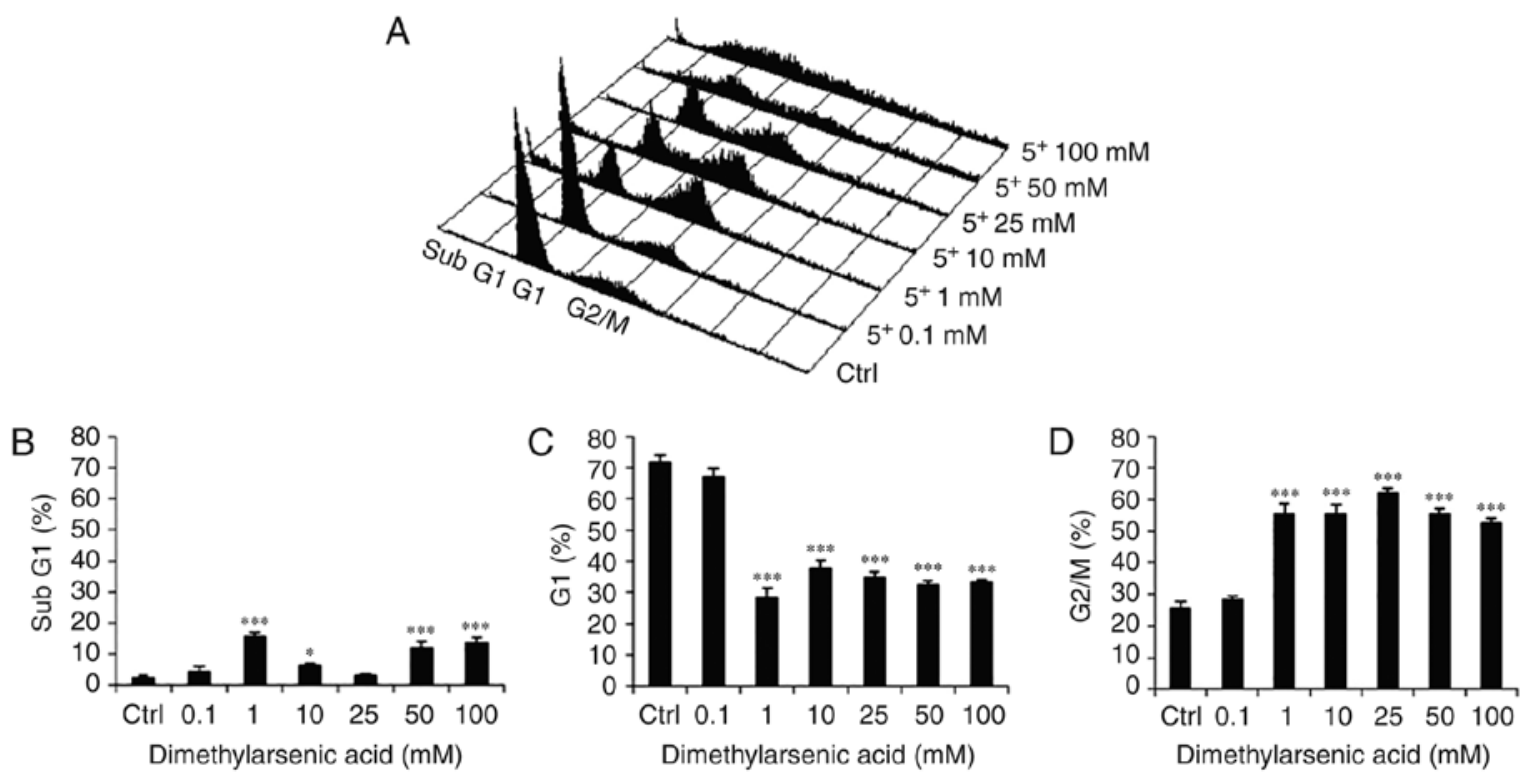

Figure 4. Effects of DMA on cell cycle redistribution in OEC-M1 cells. (A) Various concentrations of DMA (0, 0.1, 1, 10, 25, 50 and $100 \mathrm{mM})$ were used to treat OEC-M1 for $24 \mathrm{~h}$. Cells were fixed, stained with PI, and analyzed by flow cytometry. Cells in subG1 phase contain less DNA content than normal cells, indicating apoptosis. The percentage of (B) sub G1, (C) G1 and (D) G2/M phase cells are presented, respectively. The data are expressed as the mean \pm SEM of at least three separate experiments. ${ }^{*} \mathrm{P}<0.05$ and ${ }^{* * *} \mathrm{P}<0.001$ represent statistical differences compared to the Ctrl group. DMA, dimethylarsenic acid; SEM, standard error of the mean; PI, propidium iodide; Ctrl, control.

the number of cells in the subG1 phase (Fig. 4A and B); 1-100 $\mathrm{mM}$ significantly reduced the number of cells in the G1 phase (Fig. 4A and $\mathrm{C})(\mathrm{P}<0.05)$; and $1-100 \mathrm{mM}$ significantly increased the number of cells in the $\mathrm{G} 2 / \mathrm{M}$ phase (Fig. 4A and $\mathrm{D})(\mathrm{P}<0.05)$. These results demonstrated that both $\mathrm{NaAsO}_{2}$ and DMA could regulate the distribution of
OEC-M1 cells in the subG1, G1 and G2/M phases of the cell cycle to induce cell apoptosis.

Arsenic compounds induce apoptosis in OEC-M1 cells. To further confirm whether apoptosis is induced by arsenic compounds in OEC-M1 cells, double staining with Annexin V 

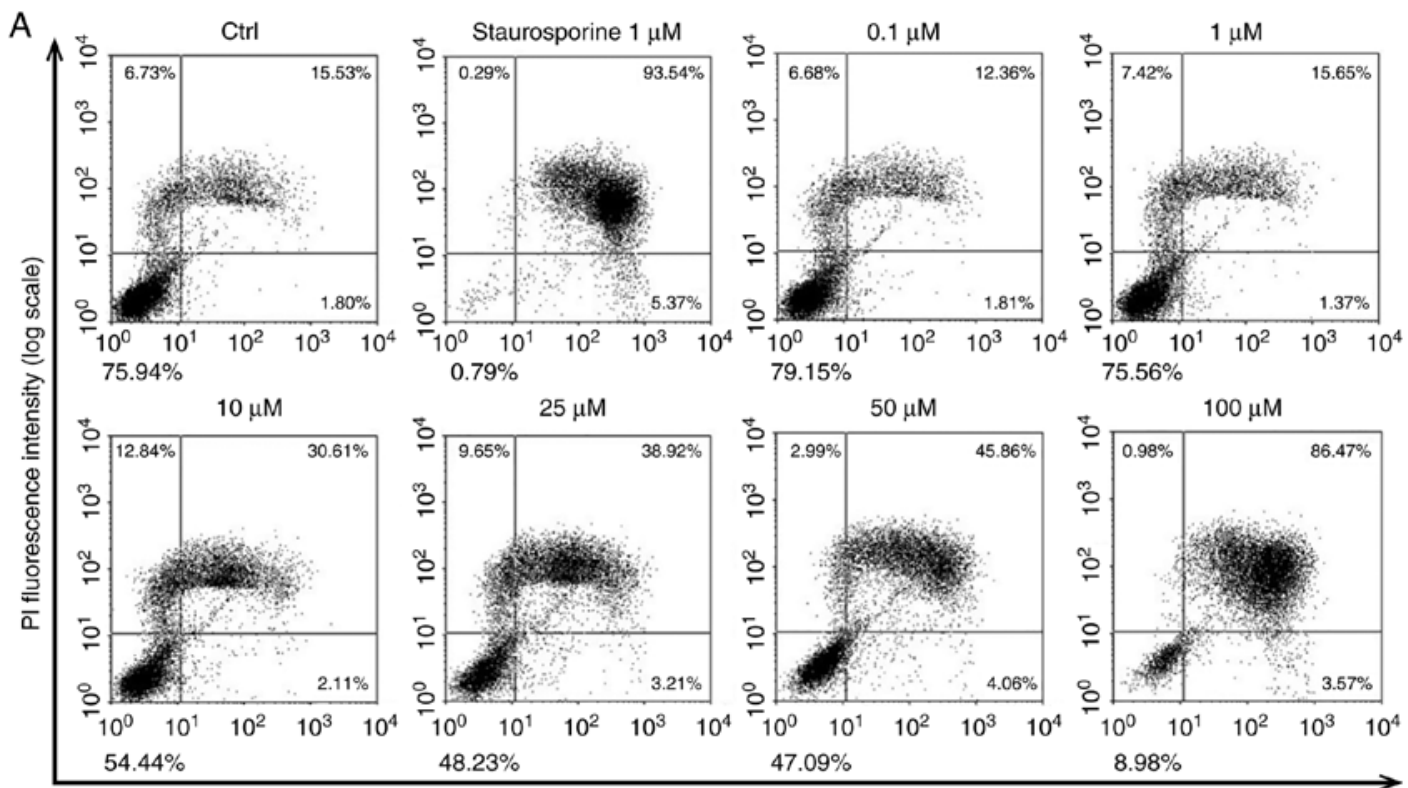

Annexin V-FITC fluorescence intensity (log scale)
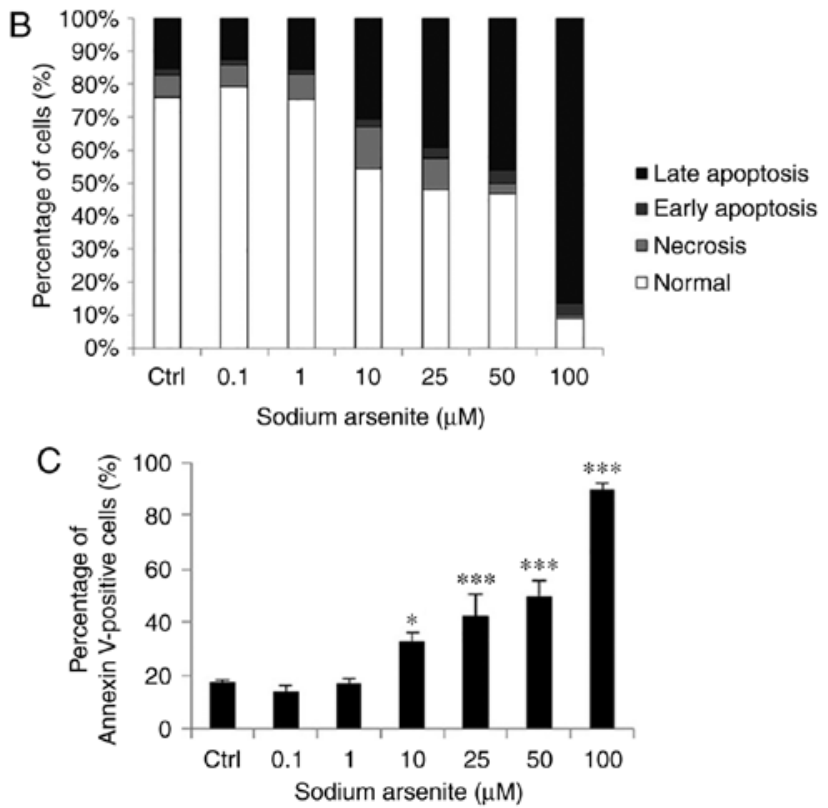

Figure 5. $\mathrm{NaAsO}_{2}$ induces OEC-M1 cell apoptosis. Various concentrations of $\mathrm{NaAsO}_{2}(0,0.1,1,10,25,50$ and $100 \mu \mathrm{M})$ were used to treat $\mathrm{OEC}$-M1 for $24 \mathrm{~h}$. (A) The apoptotic status was determined by Annexin V/PI double staining assay, and the staurosporine-treated cells were considered as a positive control. (B) The percentages of double-negative (viable), PI single-positive (necrotic), Annexin V single-positive (early apoptotic), and double-positive (late apoptotic) cells are presented in. (C) Annexin V-positive cells were analyzed and are presented. The data are expressed as the mean \pm SEM of at least three separate experiments. ${ }^{*} \mathrm{P}<0.05$ and ${ }^{* * *} \mathrm{P}<0.001$ represent statistical differences compared to the Ctrl group. $\mathrm{NaAsO}_{2}$ sodium arsenite; $\mathrm{SEM}$, standard error of the mean; PI, propidium iodide; Ctrl, control.

and PI via flow cytometer was performed. The percentages of double-negative (viable), PI-positive (necrotic), Annexin V-positive (early apoptotic) and double-positive (late apoptotic) cells can be revealed in four quadrants by the double staining assay to assess cell apoptosis (38). Treatment with $\mathrm{NaAsO}_{2}(10-100 \mu \mathrm{M})$ (Fig. 5A) and DMA (1-100 mM) (Fig. 6A) for $24 \mathrm{~h}$ significantly induced cell apoptosis, and the number of Annexin V-positive cells significantly increased as the concentrations of sodium $\mathrm{NaAsO}_{2}$ (Fig. 5B and C) and DMA increased (Fig. 6B and $\mathrm{C})(\mathrm{P}<0.05)$. These results demonstrated that both $\mathrm{NaAsO}_{2}$ and DMA promoted apoptosis of OEC-M1 cells.
Involvement of the extrinsic and intrinsic pathways of caspases in arsenic-induced OEC-MI cell apoptosis. To further investigate whether arsenic compounds can induce OEC-M1 cell apoptosis via the death receptor (extrinsic) and/or mitochondrial (intrinsic) apoptotic pathways, the expression levels of cleaved caspase- 8 and caspase- 9 , and the downstream targets of cleaved caspase- 3 and PARP were examined by western blotting (Fig. 7). The selected concentrations of $\mathrm{NaAsO}_{2}(10$ and $25 \mu \mathrm{M}$ ) and DMA (1 and $10 \mathrm{mM}$ ) used to determine the involvement of the extrinsic and intrinsic pathways in the present experiments were based on the doses that could reduce cell viability from $\sim 40$ to $60 \%$ covering $50 \%$ (Fig. 2) and 

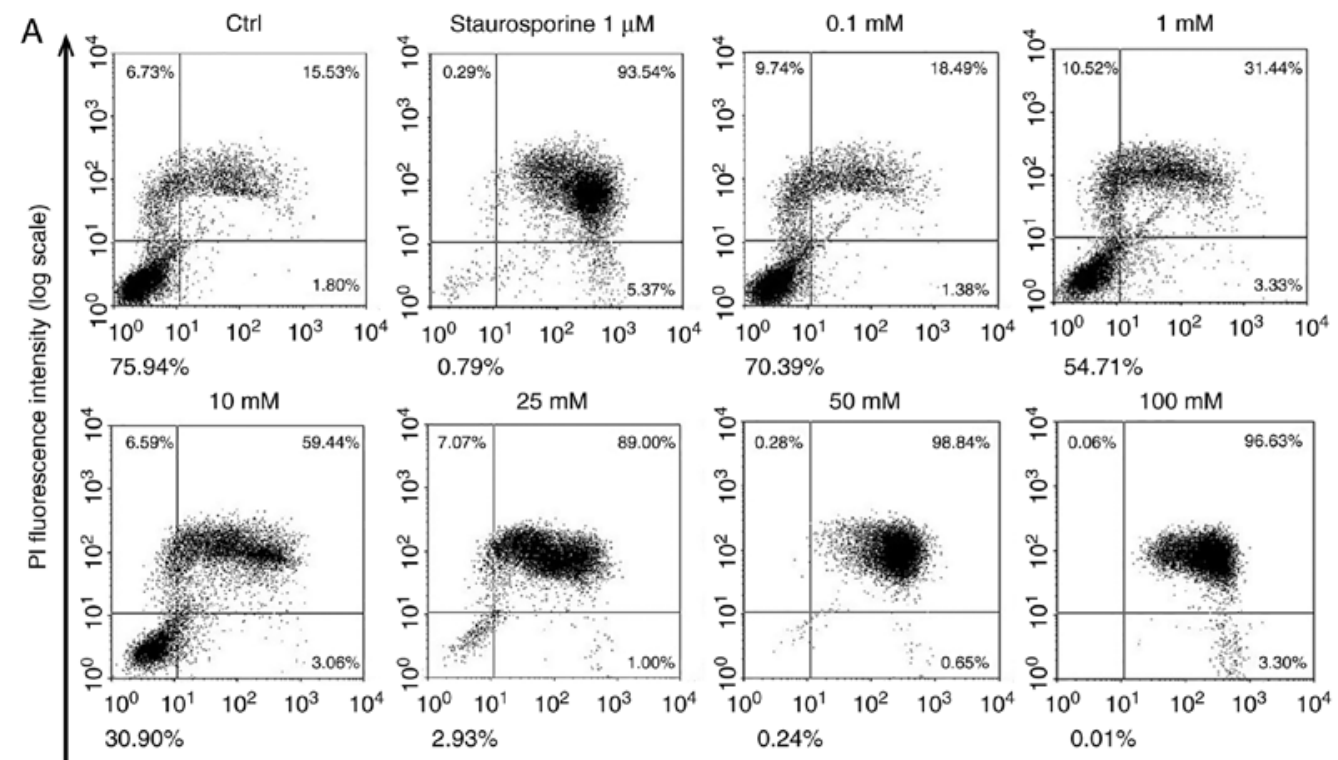

Annexin V-FITC fluorescence intensity (log scale)
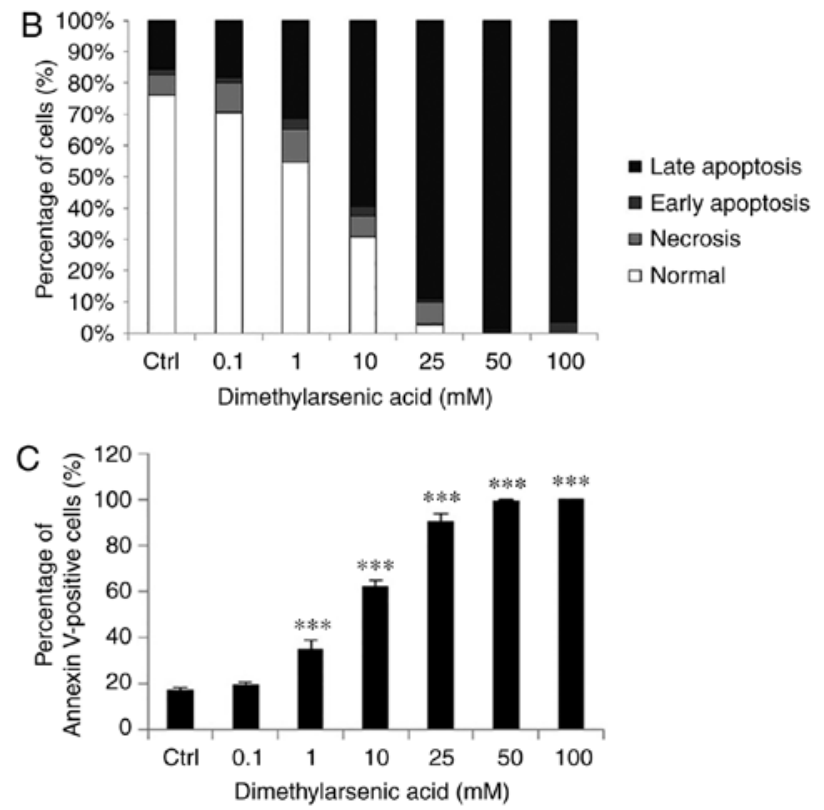

Figure 6. DMA induces OEC-M1 cell apoptosis. Various concentrations of DMA (0, 0.1, 1, 10, 25, 50 and $100 \mathrm{mM})$ were used to treat OEC-M1 for 24 h. (A) The apoptotic status was determined by Annexin V/PI double staining assay, and the staurosporine-treated cells were considered as a positive control. (B) The percentages of double-negative (viable), PI single-positive (necrotic), Annexin V single-positive (early apoptotic), and double-positive (late apoptotic) cells are presented. (C) Annexin V-positive cells were analyzed and are presented. The data are expressed as the mean \pm SEM of at least three separate experiments. ${ }^{* * *} \mathrm{P}<0.001$ represent statistical differences compared to the Ctrl group. DMA, dimethylarsenic acid; SEM, standard error of the mean; PI, propidium iodide; Ctrl, control.

induce cell apoptosis from $\sim 30$ to $45 \%$ for $\mathrm{NaAsO}_{2}$ (Fig. 5) and from $\sim 35$ to $60 \%$ for DMA, respectively (Fig. 6).

$\mathrm{NaAsO}_{2}$ at 10 and $25 \mu \mathrm{M}$ for 12 and $24 \mathrm{~h}$ significantly activated caspase-8 (Fig. 7A and B) and PARP (Fig. 7A and E), while caspase- 9 was significantly activated by 10 and $25 \mu \mathrm{M}$ $\mathrm{NaAsO}_{2}$ for $12 \mathrm{~h}$, and $25 \mu \mathrm{M} \mathrm{NaAsO}_{2}$ for $24 \mathrm{~h}$ (Fig. 7A and C) $(\mathrm{P}<0.05)$. Caspase-3 was significantly activated by treatment with $25 \mu \mathrm{M} \mathrm{NaAsO}$ for 12 and $24 \mathrm{~h}$ (Fig. 7A and D) $(\mathrm{P}<0.05)$. DMA at $1 \mathrm{mM}$ for $24 \mathrm{~h}$ could significantly induce the cleavage of caspase-8, -9, -3 and PARP (Fig. 8A-E) $(\mathrm{P}<0.05)$. The expression of cleaved PARP was also significantly increased by $10 \mathrm{mM}$ DMA for $24 \mathrm{~h}$ (Fig. $8 \mathrm{~A}$ and $\mathrm{E})(\mathrm{P}<0.05)$. In addition,
$10 \mathrm{mM}$ DMA for $12 \mathrm{~h}$ could induce cleavage of caspase-3 and PARP (Fig. 8A, D and E) $(\mathrm{P}<0.05)$. These results indicated that long-term exposure of both sodium compounds could activate caspase- 8 and caspase- 9 , followed by caspase- 3 and PARP, to induce both the extrinsic and intrinsic apoptotic pathways in OEC-M1 cells.

Involvement of the MAPK pathways in arsenic-induced apoptosis of OEC-M1 cells. Previous studies have revealed that MAPK pathways may be involved in regulating cell proliferation, differentiation, mitosis, cell survival, gene expression and apoptosis $(26,27)$. To evaluate whether MAPK pathways 
A

\begin{tabular}{|c|c|c|c|c|c|c|c|c|c|c|c|c|}
\hline \multirow[b]{2}{*}{$\mathrm{NaAsO}_{2}(\mu \mathrm{M})$} & \multicolumn{3}{|c|}{$3 \mathrm{~h}$} & \multicolumn{3}{|c|}{$6 \mathrm{~h}$} & \multicolumn{3}{|c|}{$12 \mathrm{~h}$} & \multicolumn{3}{|c|}{$24 \mathrm{~h}$} \\
\hline & c & 10 & 25 & c & 10 & 25 & c & 10 & 25 & c & 10 & 25 \\
\hline Cleaved caspase- 8 & & & & $=$ & $=$ & - & - & $=$ & $\equiv$ & $=$ & $\equiv$ & $\equiv$ \\
\hline Cleaved caspase- 9 & & & & T & & 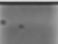 & & 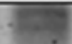 & & & - & 1 \\
\hline Cleaved caspase- 3 & $1=$ & & - & 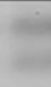 & 200 & $=0$ & 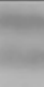 & & $=$ & 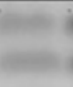 & & $m$ \\
\hline Cleaved PARP & $\square$ & 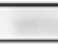 & 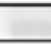 & E & 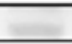 & 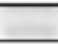 & $=$ & $=$ & $=$ & 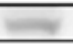 & $\Longrightarrow$ & 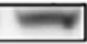 \\
\hline$\beta$-actin & E & - & & & 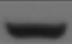 & & & - & - & $=$ & $=$ & 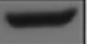 \\
\hline
\end{tabular}
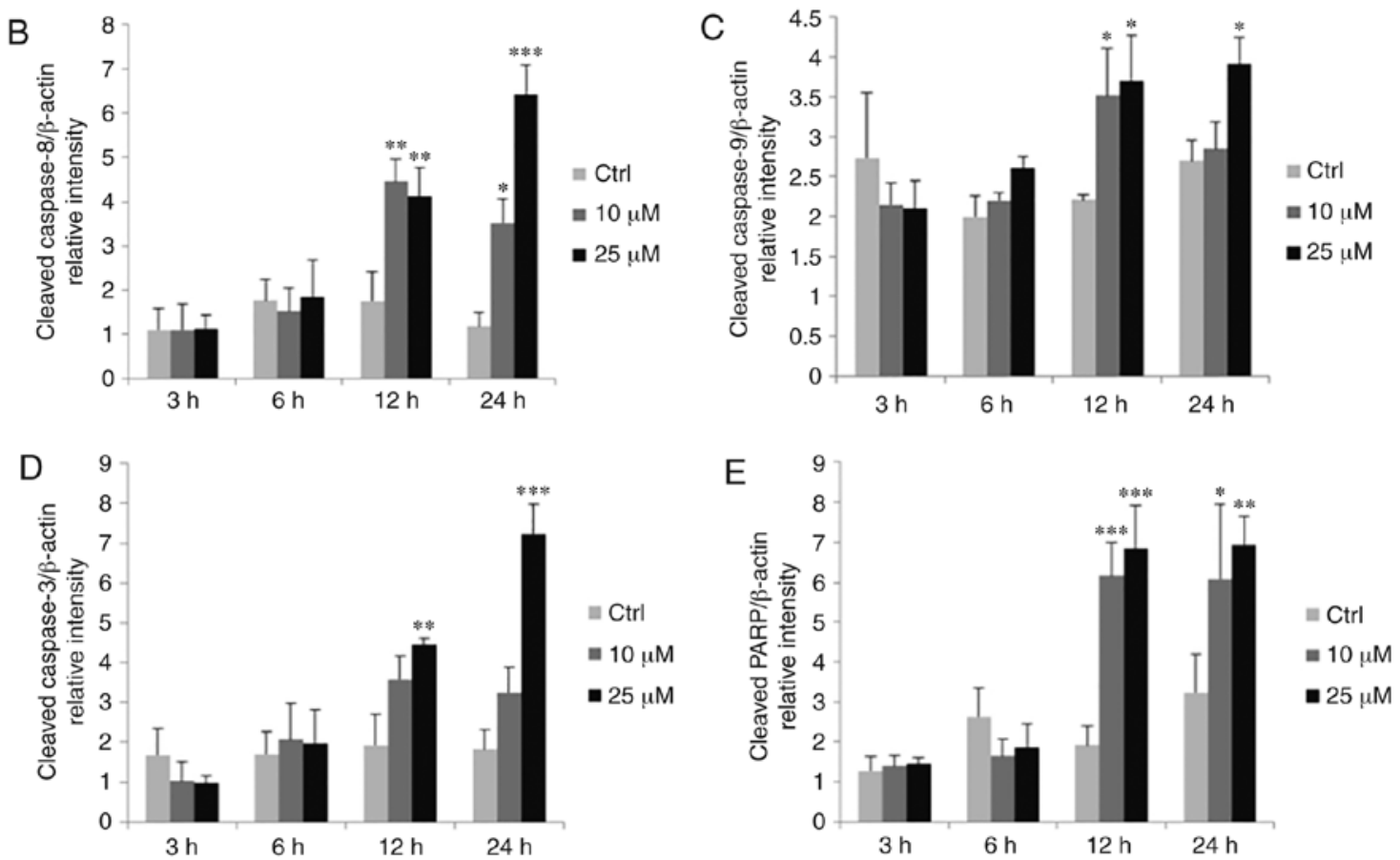

Figure 7. Effects of $\mathrm{NaAsO}_{2}$ on the expression levels of cleaved caspase-8, $-9,-3$ and PARP proteins in OEC-M1 cells. Cells were treated without or with 10 and $25 \mu \mathrm{M} \mathrm{NaAsO}_{2}$ for 3, 6, 12 and $24 \mathrm{~h}$, respectively. (A) Cleaved caspase- 8 (43 kDa), $-9(35 / 37 \mathrm{kDa}),-3(17 / 19 \mathrm{kDa})$ and PARP $(\sim 85-90 \mathrm{kDa})$ were detected by western blotting. The IODs of cleaved (B) caspase- 8 , (C) caspase-9, (D) caspase-3 and (E) PARP proteins were normalized with $\beta$-actin (43 kDa) in each lane. The data are expressed as the mean \pm SEM of at least three separate experiments. ${ }^{*} \mathrm{P}<0.05,{ }^{* * *} \mathrm{P}<0.01$, and ${ }^{* * * *} \mathrm{P}<0.001$ represent statistical differences compared to the Ctrl group. $\mathrm{NaAsO}_{2}$, sodium arsenite; PARP, poly(ADP-ribose) polymerase; IODs, integrated optical densities; SEM, standard error of the mean; C or Ctrl, control.

are associated with arsenic compound-induced OEC-M1 cell apoptosis, the phosphorylation of JNK, ERK1/2 and p38 was investigated using western blotting.

$\mathrm{NaAsO}_{2}$ at $10 \mu \mathrm{M}$ for $24 \mathrm{~h}$ and $25 \mu \mathrm{M}$ for 3,6 and $24 \mathrm{~h}$ could significantly increase the level of p-JNK (Fig. 9A and B), while $25 \mu \mathrm{M} \mathrm{NaAsO}$ for 3, 6, 12 and $24 \mathrm{~h}$ significantly increased the expression of p-ERK1/2 (Fig. 9A and C) $(\mathrm{P}<0.05)$. The p-p38 level could be significantly increased by $25 \mu \mathrm{M} \mathrm{NaAsO}_{2}$ for 6 and $24 \mathrm{~h}$ (Fig. 9A and D) $(\mathrm{P}<0.05)$. DMA at $10 \mathrm{mM}$ for $3,6,12$ and $24 \mathrm{~h}$ could significantly increase the level of p-JNK (Fig. 10A and B), and $10 \mathrm{mM}$ DMA for 6,12 and 24 could significantly increase the level of p-ERK1/2 (Fig. 10A and C) $(\mathrm{P}<0.05)$. The $\mathrm{p}-\mathrm{p} 38$ level was significantly increased after treatment with $10 \mathrm{mM}$ DMA for $24 \mathrm{~h}$ (Fig. 10A and D) $(\mathrm{P}<0.05)$.

\section{Discussion}

In the present study, $\mathrm{NaAsO}_{2}$ (inorganic arsenic) and DMA (organic arsenic) both demonstrated the ability to induce apoptosis of OEC-M1 oral cavity cancer cells. Studies have revealed that the cytoskeleton may be a target of $\mathrm{NaAsO}_{2}$ and DMA $(39,40)$, and the extent of morphological changes upon modulating the cytoskeleton correlates with drug concentration and incubation time (41). The present results demonstrated that $\mathrm{NaAsO}_{2}$ resulted in a higher number of shriveled and floating cells with increasing concentration compared with DMA in OEC-M1 cells. In addition, a greater extent of membrane blebbing cells could be observed, and floating cells tended to assemble at 50-100 mM DMA treatments. Compared with cells with abalone-like shape under lower doses of $\mathrm{NaAsO}_{2}$, high doses of DMA induced cells to attach to the ground matrix but almost rounded up, while higher doses caused cells to float in clusters. The regulatory mechanisms through which arsenic compounds lead to different cell morphologies are unknown. However, the results indicated that their effect on the cytoskeleton differs with drug types and concentrations.

Inorganic arsenic is significantly more toxic compared with organic arsenic compounds (42). Once entering the food 
A
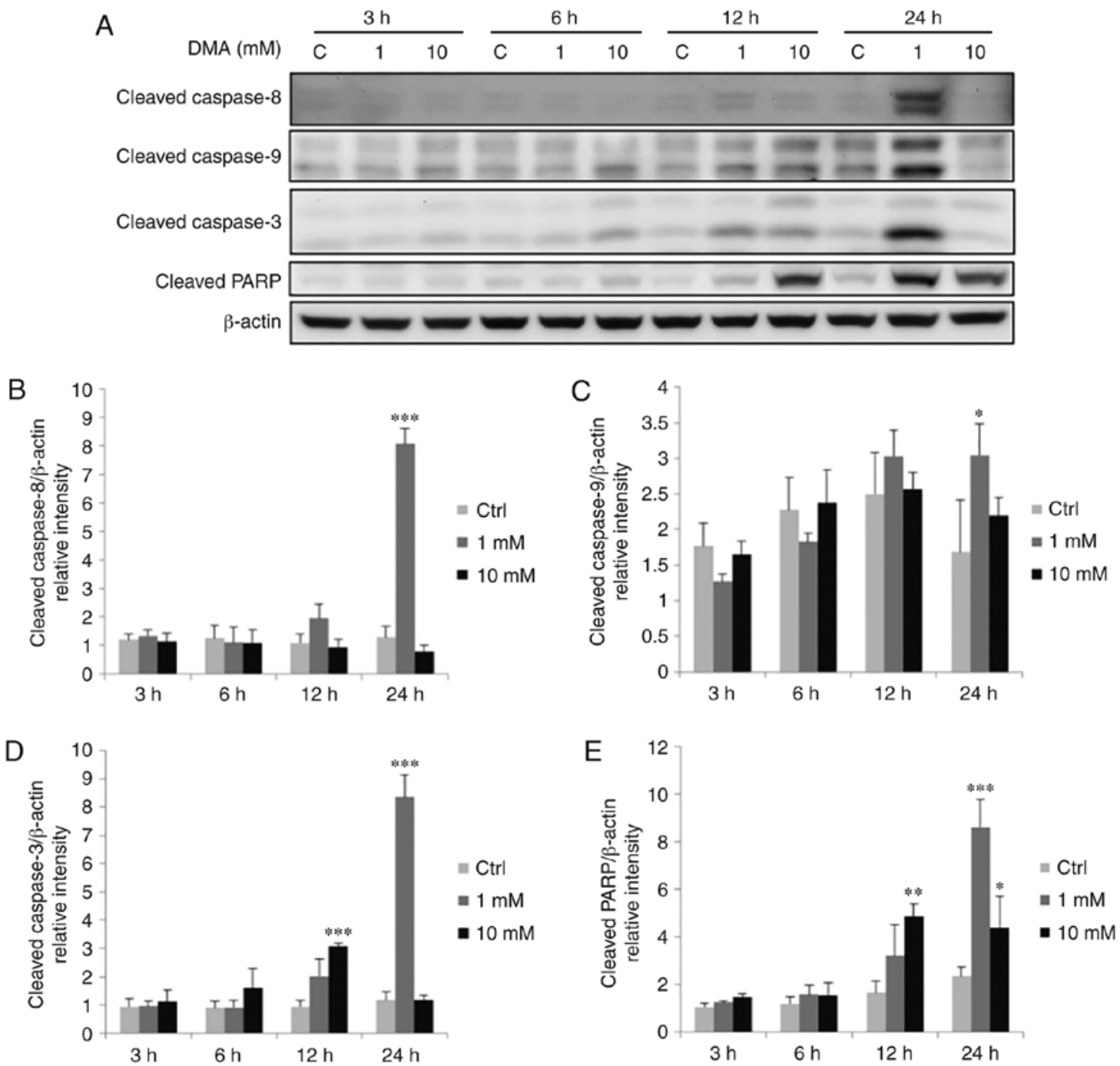

Figure 8. Effects of DMA on the expression levels of cleaved caspase-8, $-9,-3$ and PARP proteins in OEC-M1 cells. Cells were treated without or with 1 and $10 \mathrm{mM}$ DMA for 3, 6, 12 and $24 \mathrm{~h}$, respectively. (A) Cleaved caspase-8 (43 kDa), $-9(35 / 37 \mathrm{kDa}),-3(17 / 19 \mathrm{kDa})$ and PARP $(\sim 85-90 \mathrm{kDa})$ were detected by western blotting. The IODs of cleaved (B) caspase- 8 , (C) caspase-9, (D) caspase-3 and (E) PARP proteins were normalized with $\beta$-actin (43 kDa) in each lane. The data are expressed as the mean \pm SEM of at least three separate experiments. ${ }^{*} \mathrm{P}<0.05,{ }^{* * *} \mathrm{P}<0.01$, and ${ }^{* * *} \mathrm{P}<0.001$ represent statistical differences compared to the Ctrl group. DMA, dimethylarsenic acid; PARP, poly(ADP-ribose) polymerase; IODs, integrated optical densities; SEM, standard error of the mean; $\mathrm{C}$ or Ctrl, control.

chain, inorganic compounds could be metabolized by methyltransferases in the liver of several mammalian species (42). Inorganic arsenic could also be methylated to less toxic compounds, which is considered to be a detoxification reaction. For example, DMA arises from the methylation of arsenic oxide (43). In the present study, $\mathrm{NaAsO}_{2}$ and DMA decreased OEC-M1 cell viability in a dose-dependent manner, which was consistent with the results of the morphological analysis. The concentration of $\mathrm{NaAsO}_{2}$ required to perform similar effects was 1,000-fold lower compared with that of DMA, indicating that $\mathrm{NaAsO}_{2}$ exhibited stronger cytotoxicity than DMA in OEC-M1 oral cancer cells.

The eukaryotic cell cycle proceeds to the next phase as the upstream events fulfill the requirements of checkpoints (44). When undergoing cellular damage, cells may become arrest at certain phases and may undergo programmed cell death if the damage is not properly repaired (44). It has been reported that arsenite can promote disruption of the microtubule network, resulting in spindle abnormalities and, thus, mitotic cell apoptosis (45). In fact, arsenic-induced mitotic arrest may be a necessary step for the activation of apoptotic pathways in numerous human tumor cell lines (46). A previous study has also demonstrated a strong correlation between $\mathrm{G} 2 / \mathrm{M}$ arrest and the induction of apoptosis in ovarian carcinoma cell lines in response to DNA damage (47). It is well known that the subG1 phase is considered as a sign of DNA fragmentation, which indicates cell apoptosis (48), and a previous study has also revealed that $\mathrm{G} 2 / \mathrm{M}$-phase arrest can induce cells to undergo apoptosis (49). In the present study, $\mathrm{NaAsO}_{2}$ and DMA significantly induced G2/M-phase arrest and increased the number of subG1-phase cells, which suggests that both arsenic compounds could induce apoptosis of OEC-M1 cells. Hence, the present data indicated that arsenic-induced apoptosis is associated with abnormal cell cycle redistribution. The Annexin V/PI double-staining assay further verified that the induction of apoptosis by $\mathrm{NaAsO}_{2}$ and DMA occurred in a dose-dependent manner in OEC-M1 cells. However, the examination of cell cycle protein levels was not conducted in 

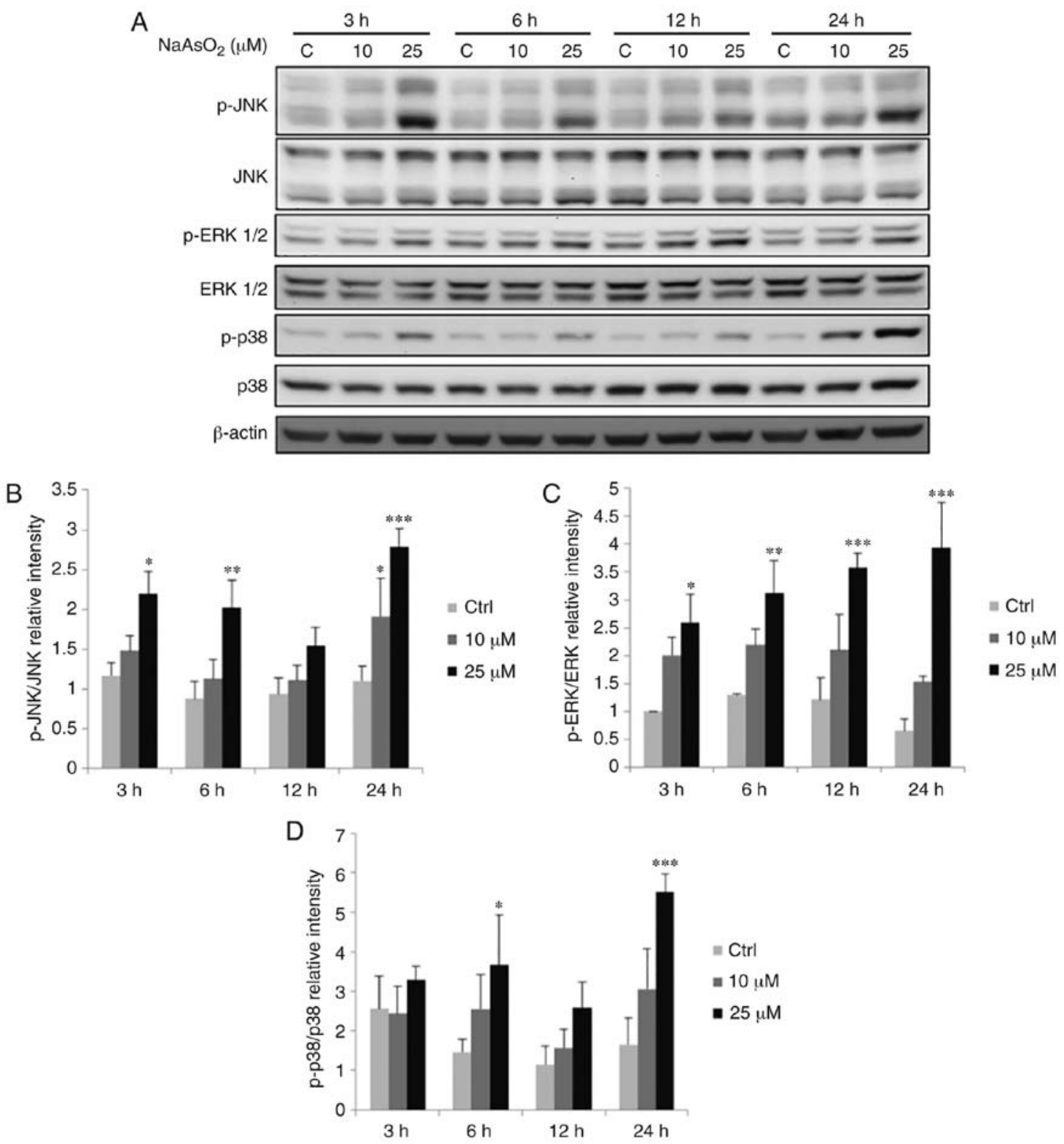

Figure 9. Effects of $\mathrm{NaAsO}_{2}$ on the phosphorylation of the MAPK signaling pathway in OEC-M1 cells. Cells were treated without or with 10 and $25 \mu \mathrm{M}$ $\mathrm{NaAsO}_{2}$ for 3, 6, 12 and $24 \mathrm{~h}$, respectively. (A) p-JNK (46/54 kDa), JNK, p-ERK1/2 (42/44 kDa), ERK1/2, p-p38 (43 kDa) and p38 were detected by western blotting. The IODs of (B) p-JNK, (C) p-ERK and (D) p-p38 proteins were normalized with total forms of themselves in each lane. The data are expressed as the mean \pm SEM of at least three separate experiments. ${ }^{*} \mathrm{P}<0.05,{ }^{* * *} \mathrm{P}<0.01$, and ${ }^{* * * *} \mathrm{P}<0.001$ represent statistical differences compared to the Ctrl group. $\mathrm{NaAsO}_{2}$, sodium arsenite; MAPK, mitogen-activated protein kinase; p-, phosphorylated; JNK, c-Jun NH2-terminal kinase; ERK, extracellular signal-regulated kinase; IODs, integrated optical densities; SEM, standard error of the mean; C or Ctrl, control.

the present study, and it is worth investigating, in a future study, at cellular and molecular levels how the expression of cell cycle proteins are regulated by $\mathrm{NaAsO}_{2}$ and DMA to induce OEC-M1 cell apoptosis. Similar to the cell viability assay, once again, $\mathrm{NaAsO}_{2}$ demonstrated 1,000-fold stronger effects compared with DMA on cell cycle regulation in OEC-M1 oral cancer cells.

Apoptosis is a critical process for maintaining homeostasis (50). Dysregulation of apoptosis is considered to be a key factor in the development of cancer (50). It is well known that apoptosis is initiated by either an extrinsic or an intrinsic death signal, and executed by the activated caspase cascade (51). It is reported that arsenic trioxide can induce the apoptosis of laryngeal cancer cells via downregulation of survivin mRNA, which inhibits activation of caspases (52). Arsenic trioxide also induces apoptosis in different cancers by activating caspase-8, -9 and -3 (11,53). In the present study, the expression levels of cleaved caspase- $8,-9,-3$ and the downstream substrate PARP were found to be increased by both $\mathrm{NaAsO}_{2}$ and DMA in OEC-M1 cells, and $\mathrm{NaAsO}_{2}$ did exhibit a stronger activating effect compared with DMA. Thus, these results supported that both arsenic compounds induced oral cavity cancer cell apoptosis through extrinsic and intrinsic apoptotic pathways. It should be noted that, in the results, the expression of some caspases was most prominently increased by DAM at $1 \mathrm{mM}$, but not at $10 \mathrm{mM}$. It is highly possible that DAM at $1 \mathrm{mM}$ has the maximal effect on the caspase pathway, which then starts to degrade. Thus, DAM at $10 \mathrm{mM}$ could not induce a 

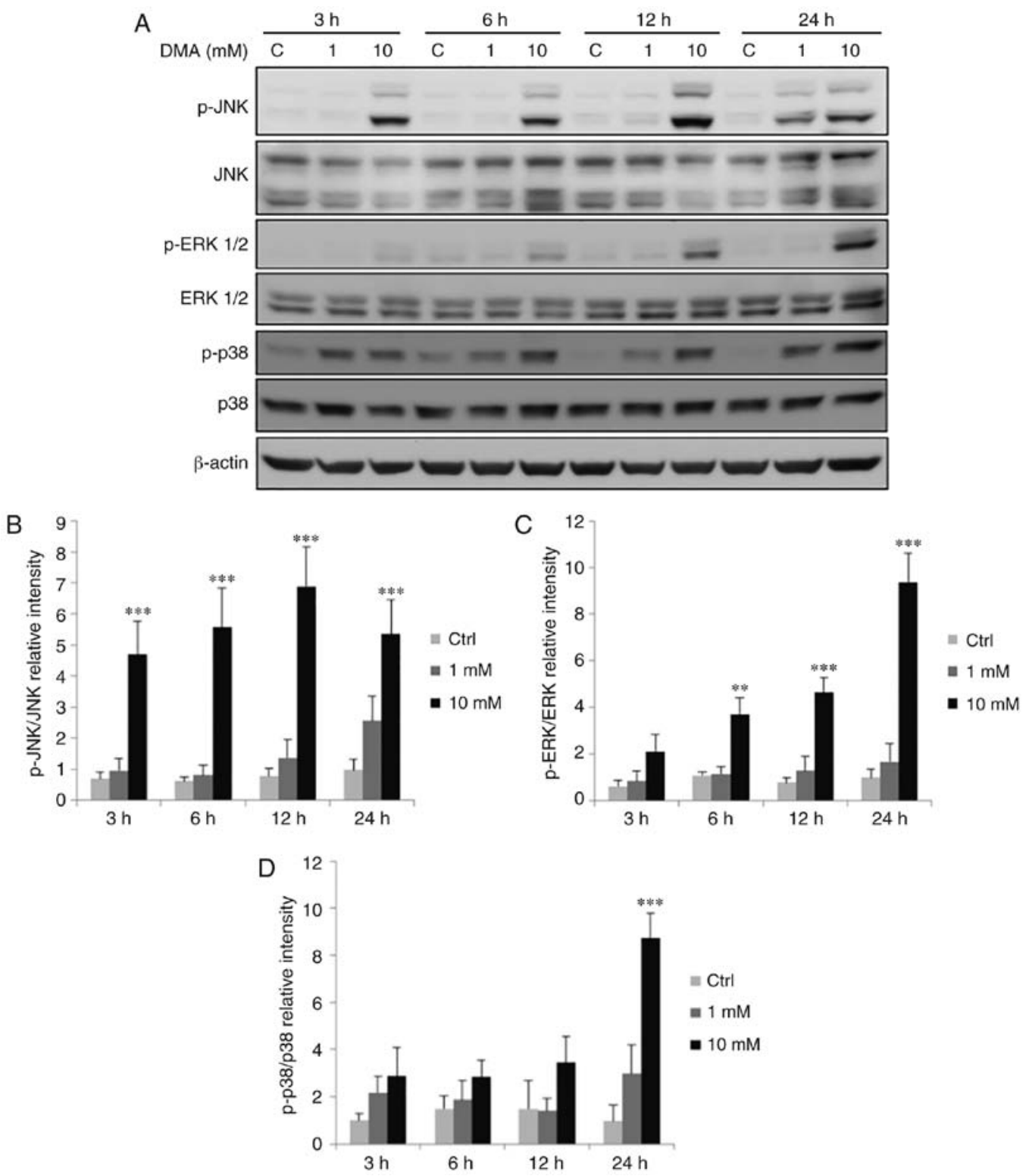

Figure 10. Effects of DMA on the phosphorylation of the MAPK signaling pathway in OEC-M1 cells. Cells were treated without or with 1 and $10 \mathrm{mM}$ DMA for 3, 6, 12 and $24 \mathrm{~h}$, respectively. (A) p-JNK (46/54 kDa), JNK, p-ERK1/2 (42/44 kDa), ERK1/2, p-p38 (43 kDa) and p38 were detected by western blotting. The IODs of (B) p-JNK, (C) p-ERK and (D) p-p38 proteins were normalized with total forms of themselves in each lane. The data are expressed as the mean \pm SEM of at least three separate experiments. ${ }^{* *} \mathrm{P}<0.01$ and ${ }^{* * * *} \mathrm{P}<0.001$ represent statistical differences compared to the Ctrl group. DMA, dimethylarsenic acid; MAPK, mitogen-activated protein kinase; p-, phosphorylated; JNK, c-Jun NH2-terminal kinase; ERK, extracellular signal-regulated kinase; IODs, integrated optical densities; SEM, standard error of the mean; C or Ctrl, control.

greater effect on OEC-M1 cell apoptosis. In addition, DAM exclusively induced some caspases at a concentration of $1 \mathrm{mM}$, indicating that phosphorylation of JNK, ERK and p38, significantly induced by DAM at $10 \mathrm{mM}$, could not be associated with the activation of caspases. In fact, DAM at $10 \mathrm{mM}$ also induced the cleavage of PARP at $24 \mathrm{~h}$. It is highly possible that the expression of cleaved caspase- $8,-9$ and -3 had degraded at $24 \mathrm{~h}$ after the treatment of DAM. Thus, DAM at $10 \mathrm{mM}$ could stimulate phosphorylation of JNK, ERK and p38, and then further induce the caspase pathway.

In fact, studies have reported that arsenic compounds can activate different signaling pathways to induce cell death related to apoptotic pathways among different cancer cell types, such as myeloma cells, neutrophils and/or leukemia (54-58). Studies have demonstrated that arsenic compounds could only activate the caspase- 8 pathway to induce human melanoma cell apoptosis by enhancing TRAIL-induced apoptosis with the suppression of the NF- $\kappa$ B and STAT3-transcriptional targets (59) and could only stimulate the caspase- 9 pathway to induce liver cancer cell apoptosis by downregulating phosphorylated-STAT3 expression with Bcl-2, XIAP, and surviving proteins (60), respectively. Studies have also revealed that arsenic compounds could activate both the caspase- 8 and caspase- 9 pathways concurrently to induce myeloma and promonocytic leukemia cell apoptosis by decreasing the expression of $\mathrm{Bcl}-2$ families and/or regulating p38-MAPK process $(61,62)$. In the present study, $\mathrm{NaAsO}_{2}$ and DMA could concurrently induce both the caspase- 8 and -9 pathways in OEC-M1 cells, indicating that our observations are not unprecedented. It is well 
known that up- and downstream of the caspase-8 and -9 pathways, pathways including Fas/Fas ligand, BCL-2, ER stress, and/or p53, are markedly involved with the finer regulation of cancer cell apoptosis (59-62). Thus, it is worth further investigating how caspase- 8 and -9 pathways are regulated by up- and downstream regulators to induce OEC-M1 cell apoptosis.

Apoptotic pathways are associated with numerous regulating mechanisms, one of which is the MAPK signaling pathway responding to cellular stress. MAPK signaling may either promote survival or enhance sensitivity to apoptosis depending on the cell types, stimuli and the latency of the activation of MAPKs $(26,27)$. In the present study, p-JNK, p-ERK1/2 and p-p38 were all increased by both $\mathrm{NaAsO}_{2}$ and DMA in OEC-M1 cells. These results indicated that both $\mathrm{NaAsO}_{2}$ and DMA could activate the phosphorylation of JNK, ERK1/2 and/or p38 to induce apoptosis in OEC-M1 cells. Notably, these results demonstrated that activation of caspases and PARP was observed following treatments with arsenic compounds for 12 and $24 \mathrm{~h}$, and the phosphorylation of MAPK occurred 3-6 h earlier compared with the caspase-mediated pathway, indicating that arsenic compounds possibly activated MAPK pathways prior to the caspases and PARP to induce apoptosis in OEC-M1 cells. It should be noted that $1 \mathrm{mM}$ DMA significantly suppressed OEC-M1 cell viability, affected the cell cycle, increased the number of apoptotic cells and activated caspase proteins, but not MAPK proteins. With a closer examination of the western blot results, $1 \mathrm{mM}$ DMA induced an increasing trend of MAPK protein expression although there was no statistical difference. Thus, these observations demonstrated that arsenic compounds activated different MAPK pathways first and then induced apoptosis in OEC-M1 oral cavity cells, which is consistent with the findings of other studies that have revealed that the induction of MAPK pathways and then caspase cascade under stimuli occurs in sequence (63-65).

In the present study, both $\mathrm{NaAsO}_{2}$ and DMA could induce cell apoptosis through extrinsic and intrinsic apoptotic pathways, exerting potential antitumor effects on OEC-M1 oral cancer cells. Furthermore, both arsenic compounds were able to induce phosphorylation of JNK, ERK and p38 MAPKs to modulate the activation of the caspase cascade to stimulate apoptosis of OEC-M1 cells. However, the precise roles upon the activation of MAPK and caspase pathways by $\mathrm{NaAsO}_{2}$ and DMA in OEC-M1 cells remain elusive, since specific inhibitors and/or siRNA were not used in the present study to block apoptosis. With the use of specific inhibitors and/or siRNA to suppress OEC-M1 cell apoptosis, the activation of MAPK and caspase pathways by $\mathrm{NaAsO}_{2}$ and DMA in OEC-M1 cells can then be confirmed, which will conclusively reveal the underlying molecular mechanism. In addition, studies have demonstrated that intravenous arsenic trioxide and its derivatives both alone and/or in combination with other agents have been used successfully for the treatment of APL and myeloid neoplasms, and arsenic trioxide is a standard treatment for APL patients to date $(66,67)$. In fact, oral liquid and pill formulations of arsenic trioxide have recently entered clinical practice for APL patients $(66,67)$. Clinical trials involving arsenic compounds have never been applied to head and neck cancers for their possible use in clinical practice. With the observations in the present study, $\mathrm{NaAsO}_{2}$ and DMA could possibly be applied for the therapy of oral cancers with intravenous infusion and/or oral intake as a tablet or pill $(66,67)$. Thus, clinical trials should be performed with arsenic compounds in order to possibly provide a helpful alternative method for the treatment of oral cancers.

It should be noted that the error bars are rather sizable in certain figures, regarding the western blot analysis of caspase and MAPK protein expression activated by $\mathrm{NaAsO}_{2}$ and DMA in OEC-M1 cells. It is well known that in in vitro cell culture experiments, the expression levels of proteins may markedly vary due to the cell conditions related to the cell passages, cell quality, and cell seeding number with the possible changes in experimental room temperature and humidity, incubator temperature and humidity, western blot-conducting skills, and the integrating optical intensities of protein bands with UVP skills. In addition, the original data from 3 independent experiments without replicates for each treatment were used to perform statistical analysis and to draw figures in the present study. Thus, the error bars became rather sizable. Reliably, the statistical analysis could still show there are differences between treatments. Thereafter, in a future study, the same experiment should be repeated more than 3 times with 2 and/or 3 more replicates in each treatment, which could decrease error bar values and increase the fidelity of results. In conclusion, $\mathrm{NaAsO}_{2}$ and DMA stimulated the extrinsic and intrinsic apoptotic pathways through the activation of MAPK pathways to induce apoptosis in OEC-M1 cells, demonstrating that both arsenic compounds exhibit promising antitumor properties and may be used for clinical therapy with marked potential for oral cancers.

\section{Acknowledgements}

Not applicable.

\section{Funding}

The present study was supported by the Ministry of Science and Technology of Taiwan, R.O.C (grant no. MOST106-2811-B-006-014, to BMH) and An-Nan Hospital, Taiwan, R.O.C (grant no. ANHRF108-20, to NPF, CLK, ECS and BMH).

\section{Availability of data and materials}

The data that support the findings of this study are available from the corresponding author upon reasonable request.

\section{Authors' contributions}

NPF, CLK and CYC designed the experiments, carried out the experiments, interpreted the results, and wrote the manuscript. CYW, ECS and BMH participated in the design and coordination of the study, were involved in the statistical analysis of the obtained results and were responsible for the revision of the manuscript for substantive and methodological correctness. All authors read and approved the final manuscript. 


\section{Ethics approval and consent to participate}

Not applicable.

\section{Patient consent for publication}

Not applicable.

\section{Competing interests}

The authors declare that they have no competing interests.

\section{References}

1. David MC, Randal SW and Stephen YL: Head and neck cancer. Cancer 113 (Suppl 7): S1911-S1932, 2008.

2. Laraway DC, Lakshmiah R, Lowe D, Roe B and Rogers SN Quality of life in older people with oral cancer. Br J Oral Maxillofac Surg 50: 715-720, 2012.

3. Sudbø J: Human papillomavirus infection as a risk factor for squamous-cell carcinoma of the head and neck. N Engl J Med 345: 376-377, 2001.

4. Ko YC, Huang YL, Lee CH, Chen MJ, Lin LM and Tsai CC: Betel quid chewing, cigarette smoking and alcohol consumption related to oral cancer in Taiwan. J Oral Pathol Med 24: 450-453, 1995.

5. Bernier $\mathbf{J}$ and Cooper JS: Chemoradition after surgery for high-risk head and neck cancer patients: How strong is the evidence? Oncologist 10: 215-224, 2005.

6. Chen CJ, You SL, Lin LH, Hsu WL and Yang YW: Cancer epidemiology and control in Taiwan: A brief review. Jpn J Clin Oncol 32 (Suppl): S66-S81, 2002.

7. Mandal BK and Suzuki KT: Arsenic round the world: A review. Talanta 58: 201-235, 2002.

8. Calatayud M, Devesa V and Vélez D: Differential toxicity and gene expression in Caco-2 cells exposed to arsenic species Toxicol Lett 218: 70-80, 2013.

9. Shen ZX, Chen GQ, Ni JH, Li XS, Xiong SM, Qiu QY, Zhu J, Tang W, Sun GL, Yang KQ, et al: Use of arsenic trioxide $\left(\mathrm{As}_{2} \mathrm{O}_{3}\right)$ in the treatment of acute promyelocytic leukemia (APL): II Clinical efficacy and pharmacokinetics in relapsed patients. Blood 89: 3354-3360, 1997.

10. Yedjou C, Tchounwou P, Jenkins J and McMurray R: Basic mechanisms of arsenic trioxide (ATO)-induced apoptosis in human leukemia (HL-60) cells. J Hematol Oncol 3: 28, 2010.

11. Liu Q, Hilsenbeck S and Gazitt Y: Arsenic trioxide-induced apoptosis in myeloma cells: p53-dependent G1 or G2/M cell cycle arrest, activation of caspase- 8 or caspase- 9 , and synergy with APO2/TRAIL. Blood 101: 4078-4087, 2003.

12. Mandegary A, Torshabi M, Seyedabadi M, Amirheidari B, Sharif $\mathrm{E}$ and Ghahremani $\mathrm{MH}$ : Indomethacin-enhanced anticancer effect of arsenic trioxide in A549 cell line: Involvement of apoptosis and phospho-ERK and p38 MAPK pathways. Biomed Res Int 2013: 237543, 2013.

13. Wang HY, Zhang B, Zhou JN, Wang DX, Xu YC, Zeng Q, Jia YL, $\mathrm{Xi} \mathrm{JF}, \mathrm{Nan} \mathrm{X}, \mathrm{He} L J$, et al: Arsenic trioxide inhibits liver cancer stem cells and metastasis by targeting SRF/MCM7 complex. Cell Death Dis 10: 453, 2019.

14. Kim EY, Lee SS, Shin JH, Kim SH, Shin DH and Baek SY: Anticancer effect of arsenic trioxide on cholangiocarcinoma: In vitro experiments and in vivo xenograft mouse model. Clin Exp Med 14: 215-224, 2014.

15. Mu YF, Chen YH, Chang MM, Chen YC and Huang BM: Arsenic compounds induce apoptosis through caspase pathway activation in MA-10 Leydig tumor cells. Oncol Lett 18: 944-954, 2019.

16. Byun JM, Lee DS, Landen CN, Kim DH, Kim YN, Lee KB Sung MS, Park SG and Jeong DH: Arsenic trioxide and tetraarsenic oxide induce cytotoxicity and have a synergistic effect with cisplatin in paclitaxel-resistant ovarian cancer cells. Acta Oncol 58: 1594-1602, 2019.

17. Kim MJ, Jung JH, Lee WS, Yun JW, Lu JN, Yi SM, Kim HJ, Chang SH, Kim GS, Hong SC and Ha WS: Arsenic hexoxide enhances TNF- $\alpha$-induced anticancer effects by inhibiting NF- $\kappa \mathrm{B}$ activity at a safe dose in MCF-7 human breast cancer cells. Oncol Rep 31: 2305-2311, 2014.
18. Nagappan A, Lee WS, Yun JW, Lu JN, Chang SH, Jeong JH, Kim GS, Jung JM and Hong SC: Tetraarsenic hexoxide induces G2/M arrest, apoptosis, and autophagy via PI3K/Akt suppression and p38 MAPK activation in SW620 human colon cancer cells. PLoS One 12: e0174591, 2017.

19. Mann KK, Wallner B, Lossos IS and Miller WH Jr: Darinaparsin: A novel organic arsenical with promising anticancer activity. Expert Opin Investig Drugs 18: 1727-1734, 2009.

20. Cheng X, Quintás-Cardama A, Golemovic M, Zingaro R, Gao MZ, Freireich EJ, Andreeff M, Kantarjian HM and Verstovsek S: The organic arsenic derivative GMZ27 induces PML-RAR $\alpha$-independent apoptosis in myeloid leukemia cells. Anticancer Res 32: 2871-2880, 2012.

21. Kasibhatla S and Tseng B: Why target apoptosis in cancer treatment? Mol Cancer Ther 2: 573-580, 2003.

22. D'Arcy MS: Cell death: A review of the major forms of apoptosis, necrosis and autophagy. Cell Biol Int 43: 582-592, 2019.

23. Ashkenazi A and Dixit VM: Death receptors: Signaling and modulation. Science 281: 1305-1308, 1998.

24. Akao Y, Nakagawa Y and Akiyama K: Arsenic trioxide induces apoptosis in neuroblastoma cell lines through the activation of caspase 3 in vitro. FEBS Lett 455: 59-62, 1999.

25. Chen GQ, Zhu J, Shi XG, Ni JN, Zhong HJ, Si GY, Jin XL, Tang W, Li XS, Xong SM, et al: In vitro studies on cellular and molecular mechanisms of arsenic trioxide $\left(\mathrm{As}_{2} \mathrm{O}_{3}\right)$ in the treatment of acute promyelocytic leukemia: $\mathrm{As}_{2} \mathrm{O}_{3}$ induces NB4 cell apoptosis with downregulation of $\mathrm{Bcl}-2$ expression and modulation of PML-RAR/PML proteins. Blood 88: 1052-1061, 1996

26. You Z, Liu SP, Du J, Wu YH and Zhang SZ: Advancements in MAPK signaling pathways and MAPK-targeted therapies for ameloblastoma: A review. J Oral Pathol Med 48: 201-205, 2019.

27. Wada T and Penninger JM: Mitogen-activated protein kinases in apoptosis regulation. Oncogene 23: 2838-2849, 2004.

28. Hayakawa J, Ohmichi M, Kurachi H, Ikegami H, Kimura A, Matsuoka T, Jikihara H, Mercola D and Murata Y: Inhibition of extracellular signal-regulated protein kinase or c-Jun $\mathrm{N}$-terminal protein kinase cascade, differentially activated by cisplatin, sensitizes human ovarian cancer cell line. J Biol Chem 274: 31648-31654, 1999.

29. Kang YH and Lee SJ: The role of p38 MAPK and JNK in Arsenic trioxide-induced mitochondrial cell death in human cervical cancer cells. J Cell Physiol 217: 23-33, 2008.

30. Yang CY and Meng CL: Regulation of PG synthase by EGF and PDGF in human oral, breast, stomach, and fibrosarcoma cancer cell lines. J Dent Res 73: 1407-1415, 1994

31. Wong DY, Chang KW, Chen CF and Chang RC: Characterization of two new cell lines derived from oral cavity human squamous cell carcinomas-OC1 and OC2. J Oral Maxillofac Surg 48: 385-390, 1990.

32. Wu WC, Hsiao JR, Lian YY, Lin CY and Huang BM: The apoptotic effect of cordycepin on human OEC-M1 oral cancer cell line. Cancer Chemother Pharmacol 60: 103-111, 2007.

33. Kang FC, Wang SC, So EC, Chang MM, Wong KL, Cheng KS, Chen YC and Huang BM: Propofol may increase caspase and MAPK pathways, and suppress the Akt pathway to induce apoptosis in MA-10 mouse Leydig tumor cells. Oncol Rep 41: 3565-3574, 2019.

34. Kang FC, Chen YC, Wang SC, So EC and Huang BM: Propofol induces apoptosis by activating caspases and the MAPK pathways, and inhibiting the Akt pathway in TM3 mouse Leydig stem/progenitor cells. Int J Mol Med 46: 439-448, 2020.

35. Lowry OH, Rosebrough NJ, Farr AL and Randall RJ: Protein measurement with the Folin phenol reagent. J Biol Chem 193: 265-275, 1951.

36. Chang MM, Lai MS, Hong SY, Pan BS, Huang H, Yang SH, Wu CC, Sun HS, Chuang JI, Wang CY and Huang BM: FGF9/FGFR2 increase cell proliferation by activating ERK1/2, $\mathrm{Rb} / \mathrm{E} 2 \mathrm{~F} 1$, and cell cycle pathways in mouse Leydig tumor cells. Cancer Sci 109: 3503-3518, 2018

37. Chang MM, Pan BS, Wang CY and Huang BM: Cordycepin-induced unfolded protein response-dependent cell death, and AKT/MAPK-mediated drug resistance in mouse testicular tumor cells. Cancer Med 8: 3949-3964, 2019.

38. van Engeland M, Ramaekers FC, Schutte B and Reutelingsperger CP: A novel assay to measure loss of plasma membrane asymmetry during apoptosis of adherent cells in culture. Cytometry 24: 131-139, 1996.

39. Li W and Chou IN: Effects of sodium arsenite on the cytoskeleton and cellular glutathione levels in cultured cells. Toxicol Appl Pharmacol 114: 132-139, 1992. 
40. Ochi T, Nakajimar F and Fukumori N: Different effects of inorganic and dimethylated arsenic compounds on cell morphology, cytoskeletal organization, and DNA synthesis in cultured Chinese hamster V79 cells. Arch Toxicol 72: 566-573, 1998.

41. Zuk A, Targosz-Korecka M and Szymonski M: Effect of selected drugs used in asthma treatment on morphology and elastic properties of red blood cells. Int J Nanomedicine 6: 249-57, 2011.

42. Vahter M: Methylation of inorganic arsenic in different mammalian species and population groups. Sci Prog 82: 69-88, 1999.

43. Lin KW, Behl S, Furst A, Chien P and Toia RF: Formation of dimethylarsinic acid from methylation of sodium arsenite in lumbricus terrestris. Toxicol In Vitro 12: 197-199, 1998.

44. Hartwell LH and Weinert TA: Checkpoints: Controls that ensure the order of cell cycle events. Science 246: 629-634, 1989.

45. Yih LH, Wu YC, Hsu NC and Kuo HH: Arsenic trioxide induces abnormal mitotic spindles through a PIP4KII $\gamma /$ Rho pathway. Toxicol Sci 128: 115-125, 2012.

46. Ling YH, Jiang JD, Holland JF and Perez-Soler R: Arsenic trioxide produces polymerization of microtubules and mitotic arrest before apoptosis in human tumor cell lines. Mol Pharmacol 62: 529-538, 2002.

47. Concin N, Stimpfl M, Zeillinger C, Wolff U, Hefler L, Sedlak J, Leodolter S and Zeillinger R: Role of p53 in G2/M cell cycle arrest and apoptosis in response to gamma-irradiation in ovarian carcinoma cell lines. Int J Oncol 22: 51-57, 2003.

48. Shu CH, Yang WK, Shih YL, Kuo ML and Huang TS: Cell cycle $\mathrm{G} 2 / \mathrm{M}$ arrest and activation of cyclin-dependent kinases associated with low-dose paclitaxel-induced sub-G1 apoptosis. Apoptosis 2: 463-470, 1997.

49. Tyagi AK, Singh RP, Agarwal C, Chan DC and Agarwal R: Silibinin strongly synergizes human prostate carcinoma DU145 cells to doxorubicin-induced growth Inhibition, G2-M arrest, and apoptosis. Clin Cancer Res 8: 3512-3519, 2002

50. Brown JM and Attardi LD: The role of apoptosis in cancer development and treatment response. Nat Rev Cancer 5: 231-237, 2005.

51. Fan TJ, Han LH, Cong RS and Liang J: Caspase family proteases and apoptosis. Acta Biochim Biophys Sin (Shanghai) 37: 719-727, 2005.

52. Cheng B, Yang X, Han Z, An L and Liu S: Arsenic trioxide induced the apoptosis of laryngeal cancer via down-regulation of survivin mRNA. Auris Nasus Larynx 35: 95-101, 2008.

53. Jiang XH, Wong BC, Yuen ST, Jiang SH, Cho CH, Lai KC, Lin MC, Kung HF and Lam SK: Arsenic trioxide induces apoptosis in human gastric cancer cells through up-regulation of p53 and activation ofcaspase-3. Int J Cancer 91: 173-179, 2001.

54. Wu X, Shi J, Wu Y, Tao Y, Hou J, Meng X, Hu X, Han Y, Jiang W, Tang S, et al: Arsenic trioxide-mediated growth inhibition of myeloma cells is associated with an extrinsic or intrinsic signaling pathway through activation of TRAIL or TRAIL receptor 2. Cancer Biol Ther 10: 1201-1214, 2010.

55. Binet F, Chiasson S and Girard D: Evidence that endoplasmic reticulum (ER) stress and caspase-4 activation occur in human neutrophils. Biochem Biophys Res Commun 391: 18-23, 2010.
56. LunghiP,Giuliani N,MazzeraL,LombardiG,Ricca M,Corradi A Cantoni AM, Salvatore L, Riccioni R, Costanzo A, et al: Targeting MEK/MAPK signal transduction module potentiates ATO-induced apoptosis in multiple myeloma cells through multiple signaling pathways. Blood 112: 2450-2462, 2008

57. Kircelli F, Akay C and Gazitt Y: Arsenic trioxide induces p53-dependent apoptotic signals in myeloma cells with SiRNA-silenced p53: MAP kinase pathway is preferentially activated in cells expressing inactivated p53. Int J Oncol 30: 993-1001, 2007.

58. Lam HK, Li K, Chik KW, Yang M, Liu VC, Li CK, Fok TF, Ng PC, Shing MM, Chuen CK and Yuen PM: Arsenic trioxide mediates intrinsic and extrinsic pathways of apoptosis and cell cycle arrest in acute megakaryocytic leukemia. Int J Oncol 27: 537-545, 2005.

59. Ivanov VN and Hei TK: Regulation of apoptosis in human melanoma and neuroblastoma cells by statins, sodium arsenite and TRAIL: A role of combined treatment versus monotherapy. Apoptosis 16: 1268-1284, 2011.

60. Shen L, Zhang G, Lou Z, Xu G and Zhang G: Cryptotanshinone enhances the effect of Arsenic trioxide in treating liver cancer cell by inducing apoptosis through downregulating phosphorylated- STAT3 in vitro and in vivo. BMC Complement Altern Med 17: 106, 2017

61. Wang X and Zhang M: Synergistic effects of valproic acid and arsenic trioxide on RPMI8226 cells in vitro and the possible underlying mechanisms. Mol Med Rep 12: 1449-1456, 2015.

62. Amrán D, Sánchez Y, Fernández C, Ramos AM, de Blas E, Bréard J, Calle C and Aller P: Arsenic trioxide sensitizes promonocytic leukemia cells to TNFalpha-induced apoptosis via p38-MAPK-regulated activation of both receptor-mediated and mitochondrial pathways. Biochim Biophys Acta 1773: 1653-1663, 2007.

63. Alvarado-Kristensson M, Melander F, Leandersson K, Rönnstrand L, Wernstedt C and Andersson T: p38-MAPK signals survival by phosphorylation of caspase- 8 and caspase- 3 in human neutrophils. J Exp Med 199: 449-458, 2004.

64. Grethe S, Ares MP, Andersson T and Pörn-Ares MI: p38 MAPK mediates TNF-induced apoptosis in endothelial cells via phosphorylation and downregulation of Bcl-x(L). Exp Cell Res 298: 632-642, 2004.

65. Choi WS, Eom DS, Han BS, Kim WK, Han BH, Choi EJ, Oh TH, Markelonis GJ, Cho JW and Oh YJ: Phosphorylation of p38 MAPK induced by oxidative stress is linked to activation of both caspase-8- and -9-mediated apoptotic pathways in dopaminergic neurons. J Biol Chem 279: 20451-2060, 2004.

66. Falchi L, Verstovsek S, Ravandi-Kashani F and Kantarjian HM: The evolution of arsenic in the treatment of acute promyelocytic leukemia and other myeloid neoplasms: Moving toward an effective oral, outpatient therapy. Cancer 122: 1160-1168, 2016.

67. Torka P, Al Ustwani O, Wetzler M, Wang ES and Griffiths EA: Swallowing a bitter pill-oral arsenic trioxide for acute promyelocytic leukemia. Blood Rev 30: 201-211, 2016. 